\title{
ラットの両側尿管結紮による実験尿毒症腎 の電子顕微鏡的研究
}

\author{
千葉大学医学部泌尿器科学教室 神谷定 治
(主任: 百瀬㴊一教授)
}

\section{ELECTRON MICROSCOPIC STUDY ON EXPERIMENTAL UREMIC RAT KIDNEY BY BILATERAL URETERAL LIGATION}

\author{
Sadaharu Kamiya \\ From Department of Urology, School of Medicine, Chiba University, Chiba, Japan
}

(Director: Prof. G. Momose)

Bilateral ureteral ligation was done on the rats to cause acute uremia, and the dripping fixation method by Maunsbach et al was carried out on thier kidneys.

The following results were obtained from light and electron microscopic observations.

1) The penetrating rate of osmium tetroxide by the dripping fixation method in my experiments was $10-15 \mu$ per minute, showing a little lower rate than $20 \mu$ per minute reported by Maunsbach et al.

2) The outer cortical tubules fixed by dripping method were not all open lumina against Maunsbach's report and conversly closed lumina were observed in greater number.

3) In the middle portion fixed by both methods of dripping and immersion, remarkable vacuoles appeared in epithelial cells of proximal tubules in both groups of uni and bilateral ureteral ligations and I regard it as an artificial change produced by the fixation.

4) With light microscopy I could not distinguish exactly between vacuoles produced by artificial change and vacuoles of a lysosome like structure, but with electron microscopy the former could be evidently distinguished from the latter. The former were vacuoles produced by separation of plasma membrane.

5) In the group of bilateral ureteral ligation, big vacuoles were observed in the visceral epithelial cells of Bowman's capsule and sometimes these vacuoles and erythrocytes were noted in urinary space of Bowman's capsule.

6) The vacuoles immediately under the microvilli of proximal tubules increased remarkably in the group of bilateral ureteral ligation.

7) In epithelial cells of proximal tubules in the group of bilateral ureteral ligation, swelling of the cytoplasm, projection of whole cells into tubular lumen or occasionally destruction of cells were observed.

8) In epithelial cells of proximal tubules in the group of bilateral ureteral ligation, vacuoles of lysosome-like structure appeared evidently and increased in proportion to the progress of hours after ligation and at last the cells were entirely filled with only these vacuoles. This finding accorded with vacuolar degeneration observed with light microscopy. Similar vacuoles were also noted very slightly in the group of unilateral ureteral ligation.

9) With light microscopy by the Gomori's method, it proved that, acid phosphatase existed in epithelial cells of proximal tubules in the group of bilateral ureteral ligation. Therefore, I regard vacuoles of lysosome-like structure as to be those which lysosome had changed.

\section{I 緒 言}

尿毒症とは何等かの原因により腎機能不全が起り，血 中残余窒素の異常増量をきたした一症候群であると一応
定義されよう。したがつて尿毒症における㹂蔵の組織変 化は,腎機能不全を起こさせる基礎的疾患と,二次的に生 じた尿毒症の変化との加味されたものであろう．よつて 
腎臟においては，純粋に尿毒症のみによつて起る変化を 観察することは困難であり, 現在まで, 腎炎や昇录中毒 などによる尿毒症の組織学的研究は数多く見られるが， 比較的純粋な, 尿毒症のみの所見を得ようとする研究は 見当らない。

一方，水腎症又は片側尿管結紮による実験的水腎症の 光学顕微鏡（以下「光顕」と略す）的検索には壁島2:)の 報告がある. 壁島は結紮後 2 時間目でボウマン襄及び尿 細管々腔の抎張が軽度に見られ，近位尿細管上皮細胞の 桿状構造の配列に乱れを認めているが，細胞内病変が顕 著となるのは数日を経てからであるといら. 又, 電子顕 微鏡（以下「電顕」と略す）による実験的尿毒症の研究 は Novicoff ${ }^{26)}$, 平井 ${ }^{20)}$, 岡田, ${ }^{28)}$ 高須 ${ }^{43}$ 等の発表があり, Novicoff ${ }^{26)}$ が片側尿管結紮後 6 時間目で近位尿細管上皮 細胞に lysosome 様空胞の出現と, microvilli を含む上 皮細胞の破壞とを認めているが，その他の人々 ${ }^{20228) 431}$ は 結禁後短時間では殆ど変化はなかつたと報告している。

Novicoff ${ }^{26)}$ のみた空胞出現も細胞全体にわたるような 著るしい病変ではなかつた。

そこで，私はなるべく炎症とか壊死等の複雑な变化を 伴わないよらな，急性腎不全による尿毒症腎の变化を求 めようと,ラッテの両側尿管完全結禁を試み，経時的に その腎臓を光顕及び電顕で観察し，あわせて血液の化学 的検査を平行して行つたので，それらの所見を報告す る。

なお，電顕の観察にあたつては固定液，固定方法，染 色方法の相違によりかなり変つた所見を呈することは既 に知られている。 ${ }^{788) 35)}$ 私は Mausbach et $\mathrm{al}^{24)}$. の行つ た滴下固定法により組織固定を行つたが，彼等とやや異 なる結果が得られたのであわせてこの点にも些かの検討 を加えた。

\section{II 実験材料及び実験方法}

実験動物には Wistar 系の雄成熟ラット（体重 160～ $390 \mathrm{~g}$ ）を使用した。尿管結紮は全てェーテル麻酔下に 背側部繸切開で後腹膜腔に入り，腎孟より約 $1 \sim 2 \mathrm{~cm}$ 下 方に拀いて結紮した．本実験に先だつて 180〜 $390 \mathrm{~g} の$ ラット 5 匹の両側尿管完全結紮を行つて, 結紮より死亡 するまでの時間を求めたところ，体重の違いによりかな りまちまちではあるが，ほ湆20４5時間位で死亡するこ とを確めた。そこで両側尿管結紮後，およそ12時間，18 時間，24時間及び死直前の各群に区別した。エーテル麻 醉のもとに，下腹部正中切開で開腹し，両腎を触診，と もに大きく腫大していることを確めたのちに，腎を覆つ
ている後腹膜を剥離して腎表面を露出し，表面を脱脂綿 で覆い，これに S-collidine ${ }^{4)}$ 緩衝液でpH 7.2〜 7.3に 調整した $1 \%$ オスミウム酸溶液 で Mausbach et $\mathrm{al}^{24)}$ らにしたがい 1 時間滴下固定を行つた．次いで薄刃のカ ミソリで腎表面にほぼ平行に，皮質を切り出し約 $1 \mathrm{~mm}$ 四 方に細切しこれを同固定液に浸漬し，更に 2 時間氷室固 定を行つた。次いで型の如く上昇エタノール脱水を行 い， $\mathrm{Iuft}^{23)}$ の方法によつてエポキシ樹脂包埋を行つ た。超薄切片作製は，ガラスナイフを用いて，PorterBlum 超ミクロトームにより行い, 水溶性ウラニウム ${ }^{45)}$ 又はアルコール性ウラニウム ${ }^{14)}$ とMillonig ${ }^{52)}$ の水酸化鉛 の二重染色を行つた．撮影には日立HS- $7 \mathrm{~S}$ 型電子顕微 鏡を使用, 直接倍率1800 12000倍で観察, 必要に応じ 適宜写真払大を行つた。

又，対照群としては正常及び片側尿管結紮群を同様に 処理して比較検討した.

光頙的には，10\%中性フォルマリン固定のパラフィン 切片を作り，H-E, PAS 等の染色を行ない，又，エポ キシ樹脂包埋よりも切片作製， toluidine blue 染色をほ ぞこして，電顕的検索の参考に供した。なお，後述の lysosome 様構造の空胞出現に対し, 酸性フォスファタ 一ゼ検出のためカコジール酸緩衝液でpH 7.2 に調整した 6.5\%グルタールアルデヒド液で腎を固定，これを凍結 切片にしpH 5 の Gomori ${ }^{15)}$ 氏液に incubation してか ら, 硫化アンモニウム溶液処理を行ない，光顕で観察し た. 又, 対照群, 実験群ともに血液残余窒素量は Urease-Nessler 法变法により, 血清電解質は焰光分析（使用 ガス, 酸素, 水素）によつて経時的に追求した。

\section{III 観察所見}

1. 化学的所見

表 1 亿示す通り, 対照群のうち, 正常群の血液残余窒 素量は15.5 26.2mg/dlの範囲にあり，5例のみではある が，ラットの正常值は拉よそ30mg/d1以下であると思われ る. 同じく対照群のらち, 片側尿管結禁群の残余窒素量 は，結禁後12〜24時間位で，一過性に $30 \sim 40 \mathrm{mg} / \mathrm{dl}$ の軽度 上昇を示すが，その後は低下を来たし，34〜36時間目で は殆ど正常と思われる $20 \mathrm{mg} / \mathrm{dl}$ 前後の值を示すにいたる.

他方, 実験群である両側尿管結紮群では, 残余窒素の 著明な増量を認める。即ち, 結禁後 1 時間目では $20 \mathrm{mg} / \mathrm{dl}$ 台と正常值を示すか，3 時間目には40mg/dl台であり，6 時間目には60mg/dl台，18時間目には $100 \mathrm{mg} / \mathrm{dl}$ 台の值を示 し，私の実験では，28時間後に最高 $228 \mathrm{mg} / \mathrm{dl}$ と正常值 の約 $7 \sim 8$ 倍の值を示した。 しかし，血液残余窒素量 
表 1

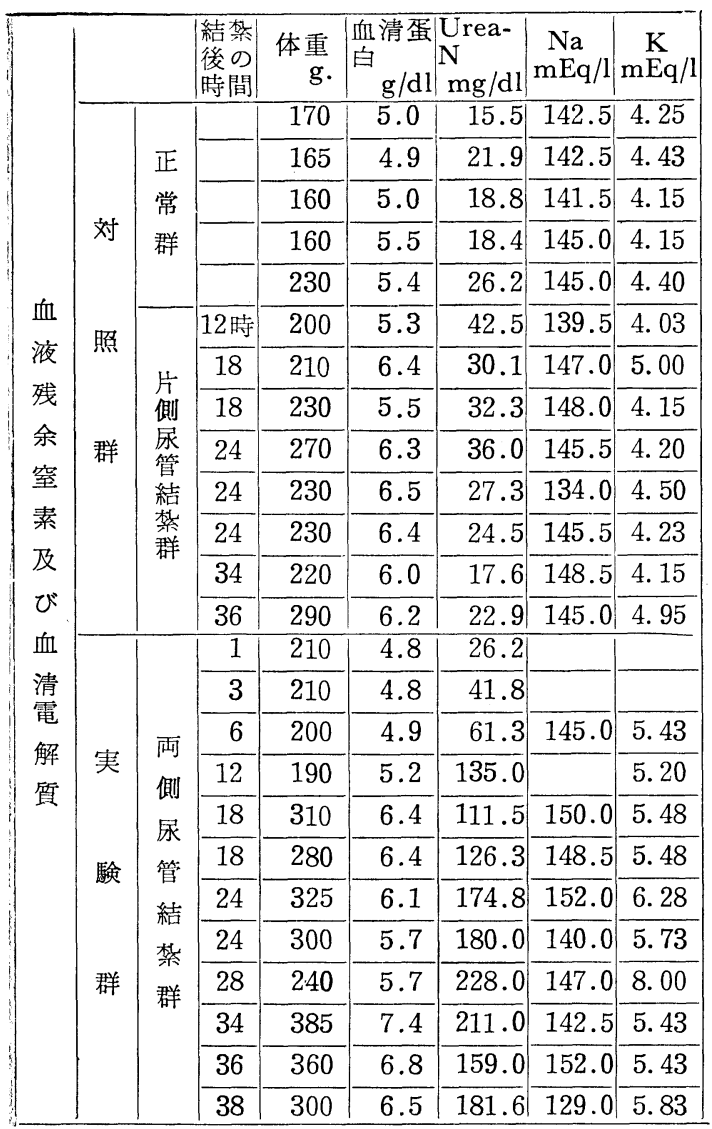

は, 初期に括いては結禁後の時間の経過に, およそ比例 して上昇を示すが，正常值の 7 ～倍程度まで上昇する と，それ以上は上昇せず，時には反つて低下を示すこと もあつた. 勿論体重差や個体差があり, 殆んどの実験動 物が結紮後30時間前後で死亡してしまうという帰結か ら，上記の傾向が絶対的なものであるかどうかはにわか 断定し難い, 又血清電解質検査のうち, 血清 $\mathrm{K}$ 值汇関 しては, 実験群の方が高値を示した. 実験例数も少ない ので正常範囲の決定は難かしいが，対照群が注ぼ 45 $\mathrm{mEq} / 1$ を示すに対し，両側尿管結禁群では殆んぞ 5 $6 \mathrm{mEq} / 1$ であり, 程度の差はあれ, K值は明らかに増 量していると考兄られる. 更に, 血清蛋白, $\mathrm{Na}$ 值に関 しては両群の間に特別な差異は認められなかつた。

\section{2. 光学顕微鏡的所見}

生きたままの状態で固定した滴下固定法と腎細切後の 浸漬固定法 (以下細切した切片を固定液中に入れし固定 する方法をこう呼ぶことにする）との相違により，組織
所見はやや異るようである。

i) 正常群

正常群では（附図 1)，滴下固定法で固定された腎表面 より $3 \sim 4$ 尿細管直径の部位まででは，尿細管々腔は開 存する場合と閉鎖する場合が観察されるが，管腔の閉鎖 しているものが多い.

次いで, 恐らく滴下固定法及び浸漬固定法の両者で固 定されたと考觉られるブロックの中間の部位ではMausbach et $\mathrm{al}^{24)}$ が述べているように尿細管々腔は開存して いる像が割に多く見られるようになり, 且つ特徵的なの は，その上皮細胞内に著明な空胞が現われることであ る. 即ち，刷子縁の下部より基底膜の方にかけて円形な いし棈円形の大小種々の，時には刷子縁より基底膜に達 するような大きな不正形の，明るい全く無構造の空胞が 認められる. 又, この部位は皮質部最外層の糸球体の存 在する所で, 系球体には上皮細胞及び内皮細胞ともに異 常所見はないが，深層の糸球体にくらべその毛細血管内 の赤血球密度は非常に高く，血管内腔は殆んぞ全てが赤 血球で占められている状態である。なお，こうした赤血 球密度の高い像は，滴下固定法で固定された外層部の尿 細管周囲の血管内，特に腎被膜直下に扣いて明らかに認 められる(附図 2).

一方，浸漬固定法で固定されたブロックの深部は，尿 細管々腔は全て閉鎖性であり，糸球体毛細血管内の赤血 球密度は前者に比し著しく低い。しかし外層部之同じく 細胞自体には特別な变化は認められない。

な拈，オスミウム酸 1 時間滴下固定後，10\%中性フォ ルマリン固定を行つた切片によつて 検索すると（附図 3 )，オスミウム酸の浸透している巾は 1 時間に特よそ 0.7 1 mm位であつた. 又, 所々のフォルマリンで固定 された部位にあたる深部の尿細管々腔には一つのネフロ ンに沿つて腎臓表面と同色の茶褐色の物質がつまつてい る所見が観察された。

ii）片腎尿管結紮群

結禁後24時間前後の所見では (附区 4 ), 正常群に比 し，ヘンレ氏係蹄，一部の遠位尿細管及び集合管の管腔 が大きく開存しているのが見られる. 又，ごく僅が見 られたのではあるが尿細管々腔内に赤血球が存在してい る像が観察された（附図 5 ).な拉，正常群で見られた滴 下固定より浸漬固定への移行部の人工的变化による空胞 形成は, やはりこの群にも明瞭に観察された。

iii）両側尿管結紮群

両側尿管結紮群も前群と同様に, 結紮後の時間の経過 
で組織所見が異なることはいらまでもない. 光顕的に明 らかに病変と思われるものが認められてくるのは, 結紮 後18時間目あたりからであり，24時間目前後からは著明 な変化が現れる。附図 6 に示したのは, 結紮後28時間目 の組織像で，血液残余窒素量は $228 \mathrm{mg} / \mathrm{dl}$ ，血清K值は $8.0 \mathrm{mEq} / 1$ を示し, 又, 全身症状として呼吸も促進し 体を突つついて刺戟を与えても幾分体を動かそうとはす るが，殆んど反応を示さない，かなり末期の症状を示し た実験例である，尿細管々腔は開存しているものが多く 近位尿細管上皮細胞内には (附図 7 ), 円形又は棈円形, 時には融合して不正形の大小種々の大きさの空胞が著明 に現れる，この明るい空胞は基底膜のまわりとか, 刷子 縁の直下に多発するとか，核のまわりに偏在するなどと いう, 一つの傾向は示さないょうで細胞内全面に散在性 に認められる. 又, この空胞内には 1 〜数コの toluidine blue で濃染する, 顆粒状物質が存在する。こうした空胞 変性は, 光䫓的に結禁後18時間目頃より認められ, その 後時間の経過とともに，急激に増加し，附図 6,7の ごとく，末期になれば近位尿細管上皮は影著な変性を見 る.な拉, 病変がひどくなると, 前記したブロック中間 部の固定による人工的変化で生じた空胞変性とは, 光顕 的にははつきり鑑別することは出来ない．しかし，後述 の如く, 電顕的にははつきりと区別することができる.

刷子縁は正常な構造を示寸ものが多いが，所々に一部 が管腔内に突出している所見が観察される。これは結杽 後, 割に早期からみられるものである（附図 7).

核及び核小体には異常所見を認めない。ヘンン氏係 蹄, 遠位尿細管, 集合管は管腔が開存するのみならず, むしろ大きく拡張しており，管腔内に赤血球及び円形の 有形成分が認められる（附図 8 ）。系球体上皮細胞飞は, はつきりした変化は認めないが，尿腔内に尿細管々腔内 に見たと同様な赤血球や，有形成分の存在するのが一部 の糸球体に認められた。（附図 9 ).

3. 電子顕微鏡的所見

糸球体，ヘンレ係蹄，遠位尿細管，集合管にはそれ程 大きな変化が認められないのに反し，著明な病的変化が 近位尿細管に認められた。

以下, 結禁後の時間の経過とともに変化する所見を対 照群と比較しながら, 釆球体と主としし病変の認められ た近位尿細管について記載する。

同一腎でもネフロンにより，対照群と全く変らない正 常なものから, 割合と変化の認められるものまで混在し て拈り, 必ずしも変化の程度も均一ではないようであ
る.

糸球体

尿腔が幾分拡張を示す以外，基底膜の厚さ及び電子密 度, 上皮細胞及び foot process の間隔, mesangium 細 胞, 毛細血管内皮細胞等は, いずれも結禁後18～20時 間位までは殆ど対照群と大差を認めない。結紮後24時間 目頃になると附図13に見られるごとく，上皮細胞質内 に, 注淮円形の $1 \sim 2 \mu$ 位の電子密度の非常に低い無構 造の空胞が出現する。結愁後28時間目の標本においては

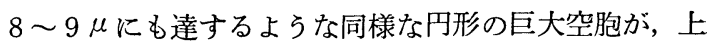
皮細胞の形質膜をから゙つたままで尿腔内に大きく突出し ている像が見られた（附図14）。空胞内は殆ど無構造であ るが，時には更に小さな小胞空を内部に認める時もあ る。

空胞は一重の膜で境されている場合もあり，附図15に 示す如く, 明らかに二重の膜で形成される場合もある。

又，同図に見られる円形の空胞は，上皮細胞と何らの連 絡もなく尿腔内に孤立して存在していた。

Golgi 装置は，規則正しく平行に並んた 6〜7 層の Golgi sac とその一部が大きく膨んで出来る Golgi vacuole 及びその周囲に近接しし見られる Golgi vesicle か ら形成されているが，この三者とも可成り良く発達して いるのが観察される(附図16).しかし，これが対照群に 比して上り高度に発達しているかどらかは分らない。

小胞体は粗面小胞体が多く見られるのに対し，滑面小 胞体はあまり観察されない。その他，円形ないし棈円形 の割に小さい mitochondria が散在性にみられるが, 膨 化したり cristae が乱れたりする所見は見当らず, 又所 々に multi-vesicular body や filament 様構造等を観察 するが，対照群との間に差は認められない.

\section{尿細管}

附図17は正常の近位尿細管上皮細胞の弱拡大である. この電顕像では，管腔は閉鎖しており， microvilli より 構成される刷子縁が右上方に, 左上方に基底膜がみられ る. 核は円形, 時に不正形で, 細胞のほぼ中心に位する ことが多いが，管腔側又は基底膜の方に偏在することも ある。細胞内には電子密度の高い円形ないし楕円形の mitochondriaが多数存在し, 所々に Golgi 装置, lysosome を認める。附図18はその強拡大で, ぎつしりとつ まつた mitochondria の間に Golgi 装置及び一重の膜: で境され, 非常に電子密度の高い円形の構造物や, 周团 の電子密度が高く, 中央は明るい円形ないし不正形の構 造物を含んだ lysosome を認める。 
次に実験群であるが，両側尿管結柇後 12 時間目頃ま では, lysosome が幾分大きくなつているょらではある が，他にはさしたる変化は認められない. 結紮後18時間 目前後になると光顕でも観察されたように，尿細管々腔 は閉鎖性のものよりも開存するものが多く見られる。附 図19はその近位尿細管直部の所見で，管腔は開存性で microvilli の配列は乱れを認めないが，直下の空胞は多 くなり, 大きさも正常に見られる小空胞から $2 \sim 3 \mu$ 位 のものまで認められ，これは正常に比し明らかに大きい ものと考兄られる. 又, 細胞中央には $3 \sim 4 \mu$ に達する 大きな電子密度の低い空胞があり, その内部には, 電子 密度の高い不正形の像が観察される. 又, 正常群でも観 察されたものであるが, microvilli 直下の空胞と, それ よりもやや電子密度の高、空胞への移行像も見られる (附図34).結紮後24時間目になると(附図20), 細胞の細 胞質の一部が大きく管腔内に microvilli の間より突出 し，茎部によつて細胞と連絡を保つているが，管腔内に は巨大空胞を形成している像が観察された，空胞内部は 細胞質密度が極度に低くなり, 殆ど無構造に見えるが, 所々に泡の上うな小空胞が存在する。更に結紮後28時 間目にては（附図21），拡張した尿細管々腔中に直径約 $4 \mu$ 位の同様な空胞構造を認めた。これは上皮細胞との 連絡は全くたたれて，管腔内に孤立していた。全く同様 な所見が系球体上皮細胞で観察されたことは前述の通り であるが，この尿細管上皮の場合も，上皮細胞と連絡が あるのか, それとも完全游離しているのかを, 直接に 証明することは困難である. 又, 時には細胞質の一部の みならず，管腔側の面全体が microvilli を伴つたまま大 きく突出している像も見られる(附図22). 即ち, 突出し た両端は terminal bar で境されて扣り, 明らかに管腔 面全体が突出していることを示している. 更に結禁後36 時間にては（附図23）,近位尿細管上皮の管腔側約 $1 / 3$ が, その電子密度が極端に低くなり, 僅かな小空胞を残して 殆ど無構造になつたままで，これまた管腔に突出してい るのが観察された. Manusbach et $\mathrm{al}^{24)} ら の$ 述べている apical swelling といら所見とはやや異なるものである が，上皮細胞の腫脹であると考学ている。なお，突出 を認める部位の microvilli は, 全部が消失するわけで はないが，かなりの部分に执いてその構造を失うことが 多い(附図22，23，24).更にこの変化が激しくなると, 上皮細胞の一部が破壊され, 変形した mitochondria が 尿細管腔中に認められる (附図).

次に, microvilli 直下の空胞は, 結紮後漸次増量し,
その18時間目の像に比し (附図19を参照),28時間目の所 見では (附図25), その数, 大きさとともに著明な增加 を来たしている，即ち辺縁はやや波をらつて不正にはな るが，直径 $4 \sim 5 \mu$ にも達する全く無構造な巨大空胞が 非常に多く存在する.

最も特徴的変化は, 近位尿細管上皮細胞内に正常では 観察されない lysosome 様構造の空胞が異常に多数出現 することである. しかもこの構造物は尿管結禁後の時間 の経過とともにしだいに増加し, ある程度尿毒症の症状 に比例するものと思われる. 附図19亿示した通り, 結紮 後18時間目の像では $3 \sim 4 \mu$ の大きさの lysosome 様空 胞がはつきりと認められ，結禁後 24 時間以上経た附図 26 では, 更に大きくなり, 棈円形の $6 \mu$ 位の巨大空胞とし て観察される. その他にも 1 数 $\mu$ の同様な空胞が細胞 内随所存在する（附図19，20，22，23，24，25，27, 28). 又, この空胞の出現の態度は, 必ずしも刷子縁の 方とか, 基底膜の側から多くなつてくるといらような一 定の傾向はない上らで, 細胞内にほ洼均等に現れる。 こ の変化が更に進行すると, 上皮細胞内は lysosome 様構 造の巨大空胞によつて，その大部分が占められてくる (附図27). mitochondria は細胞周辺部に圧排され，それ とともに basal intussusception も構造がはつきりとし なくなつてくる. microvilli 直下の空胞は, この lysosome 様構造の極端な増大により, 目立た妡見となり, 事実，数，大きさともに減少する場合も見られる（附 図25，27を比較). lysosome 様構造の空胞による変化 化が，な拈一層進行すれば，各々独立して巨大空胞化し ていたこの空胞は互に融合して（附図28），不正形とな り, 最後には, 細胞内は殆んどこの像のみとなる。

lysosome 様構造物を強拡大で観察すると，時にその 一部が不明瞭な場合もあるが，一重の限界膜で境されて いる.内部は微細顆粒で構成され，電子密度は紐胞基質 のそれと同じ位のことが多い。この微細顆粒の間にミェ リン様の層状構造物（附図29）, 電子密度の高い大きい顆 粒, 変形した mitochondria を思わせるもの（附図27, 28）等含んで括り，融合して大きくなると，こうした内 容物は, やや不明膫となる. 片側尿管結紮群にも同様の 空胞を認めたが， (附図36), その数, 大きもともに比較 になら始程少なものであつた。

なお，光顕的に対照群，実験群の両群に Gomori ${ }^{15)}$ 氏法によつて酸性フォスファターゼの検出を試みた所, 附図10，11，12に示すごとく, 両群ともに近位尿細管上 皮細胞内にそれを証明した。 又その量に関しては，実験 
群の方が染色の度合いが強く, かつ大きさも大であるよ らに思われるが，はつきりとは証明し難い。

対照群, 実験群ともにヘンレ氏係蹄, 遠位尿細管, 集 合管の上皮細胞自身の変化は殆ど認めない(附図30，31， 32)．管腔は拡張している像が多く見られ，赤血球及び 近位尿細管内で見られたのと同じ無構造の円形有形成分 の存在が認められる(附図31). 時には電子密度の高い顆 粒, 变形した mitochondria が観察される。しかし，そ れを包む上皮細胞には破壊を思わせる像は何等認められ ない(附図32).

近位尿細管にかなりの变化が出現する頃になると, 実 験群の糸球体, 尿細管周团の間質が離開し, 電子密度が 低く, 間質細胞は幾分離ればなれになるのが見られた (附図33).

なお，光顕的に，固定の際ブロック中間部の近位尿細 管の上皮細胞内に著明な空胞形成が認められたが，こ れを電顕で観察すると附図350如く大きな不正形の無構 造の空胞が見られ，それは基底部から入り込む basal intussusception と明らかに連絡していた。即ち, basal intussusception の離開によつて生じたものであつた。

\section{IV 考 按}

前述した通り, 本実験で検索した組織片は腎表面より 平行に $1 \sim 2 \mathrm{~mm}$ 程度の厚さで切り出されたものである為 , 皮質部の極く僅かな部分のみの所見である. Wachstein ${ }^{46)}$ が腎の組織化学の研究に招いて, 哺乳類の topography を詳述しているが, もしこれがラットにそのままあ てはまるものとすれば，私の検索した組織片は皮質及び 髄放線の部分であると考兄られ, 従つて糸球体及び尿細 管の各部位が一応組織片の中に含まれるものと思われ る。

1. 固定法の問題について

私は Mansbach et $\mathrm{al}^{24)}$ の行つた滴下固定法によつ たが，原法の 20 分間滴下ょりも幾分長い 1 時間滴下を行 つた。

光顕的に, 生きている時の腎臓の管腔は開存するのが 正常であるとの報告 (Walker et al ${ }^{47}$ ), Gottschalk et $\mathrm{al}^{16)}$ ) もあるが, 電顕的にもPease ${ }^{33)}$, Rhodin, Maunsbach et $\mathrm{al}^{24)}$ らは, 近位尿細管々腔は開存するのが生理 的であるとしている. 即ち, 浸漬固定法を用いた場合, 管腔が閉鎖するのは腎血流が途絶兄, anoxia が生じた 為であるとし，一方生きたままの状態で滴下固定を行兄 ば，血液供給がよく保たれ，固定される瞬間まで細胞は 正常状態が保たれることによるという. しかし, 私の標
本では, 生きたままの滴下固定を行なつても, 管腔の全 てが開存するわけではなく，むしろ，閉鎖しているもの の方が多く見られた。管腔が開存するか閉鎖するかは, そのネフロンの機能状態により, 活動状態なら開存し, 静止状態なら閉鎖すると考元ることも出来る.

オスミウム酸・フオルマリンの重固定を行つたパラフ イン切片での観察では, オスミウム酸の浸透が認められ

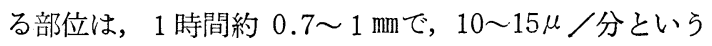
Mansbach et $\mathrm{al}^{24)}$ の值より幾分低く出た. 又, フォル マリンで固定された深部の尿細管々腔内に，一つのネフ ロンに沿つてオスミウム酸により固定されたと考兄られ る像が観察されたが，これは明らかに表在尿細管々腔内 に入つたオスミウム酸が機能の残つている系球体からの 尿流によつて下方に流れてきたことを示している．した がつて, 浸漬固定よりも一定時間内に固定される巾が大 であると思われる。

正常腎及び片側, 又は両側尿管結紮腎の全てのブロッ ク中間部の近位尿細管上皮細胞内に，固定の際に生ずる 空胞は, 電顕的には interdigitating process ${ }^{3}$ 又は basal compartment $^{50)}$ 又は basal intussusception の離開によ つて生ずるものであつた。浸漬固定法を用いて同様の所 見をラット正常腎で観察した Ruska et $\mathrm{al}^{36)}$ は intercompartment space とよび，これは細胞の機能状態によ り離開したり閉鎖したりして, 細胞から血管内への液体 吸収に関与する像であると云う. 又, Rollhäuser et $\mathrm{al}^{37)}$ はレントゲン造影剤の一種である per-obrodil 及び phenol-red の静注後にこの空胞を観察し, 病的所見とし てとり扱つている. 又 Fujibayashi et $\mathrm{al}^{13)}$ もパラアミ 八馬尿酸ソーダを負荷した腎でこれを見, Caulfield and Trump $^{6)}$ も食塩水静注後にこの所見を見ている。 しか し Mausbach et $\mathrm{al}^{24)}$ はこれを固定液の浸透圧や機械 的な非生理的因子によつて, 固定の際わずか数分内に形 成される細胞反応であるとしているが，私もこの空胞を 対照群, 実験群の全てに観察した所から彼等の見解を支 持するものである. しかし, 何故にこの空胞がブロック 中間部に現われるかは分らない。この点においてはPalay ${ }^{35)}$ らによる還流固定を行つた結果と比較検討するこ とも必要であろう.

\section{2. 片側尿管結紮腎について}

現在まで，水腎症及び片側尿管結紮による実験的水腎 症に対しては壁島 ${ }^{21)}$, Gömöri et $\mathrm{al}^{17)}$ ，岡 ${ }^{27)}$, 清水 ${ }^{40)}$, 阿曽 ${ }^{2)}$, その他多くの研究がある. 光顕的に壁島 ${ }^{21)}$ は結 
禁後 2 時間目から35日目迄の長期にわたり観察し，24時 間目では, ボウマン囊の払張を, 又部位によつて程度の 差はあるが, 細胞内病变が著明に現われるのは数日後で あるという. Gömöri et al ${ }^{17)}$ は evans-blue を結禁腎 に注入し，その排泄を，清水 ${ }^{40)}$ は腎クリアランスにより それぞれ機能回復の面から検討し，又，阿曾 ${ }^{2}$ は組織化 学的に, 岡 ${ }^{27)}$ は人間の水腎症の組織像を検索した. しか しこれらはいずれも結紮後短期間（24時間位）ではあ まり腎障害の病像を認めていない。

私の対照群としての片尿管結禁腎も, 結紫後 24 時間目 前後の所見では, 光顕的に糸球体の拡張及び近位尿細管 をのぞく尿細管の拡張が観察されたにすぎず，細胞自身 には变化は見られなかつた。

電顕による実験的水腎症の研究は Novikoff ${ }^{26)}$, 平井 ${ }^{20)}$, 岡田 ${ }^{28)}$, 高須 ${ }^{43}$ 等の報告がある. Novikoff ${ }^{26)}$ は結 柇後 6 時間目に抎張した近位尿細管上皮の核上部の microvilli 及び細胞の久損, 細胞内に変性した mitochondria 等を含むlysosome 様棈造の空胞出現を認めている ・ しかし, 岡田 ${ }^{28}$ は結紮後 $3 \sim 4$ 週間では特記すべき変 化は出現しないという. 高須 ${ }^{43)}$ も近位及び遠位尿細管に 峙結森後 7 ～10日頃より変化が現われ，その主役をなす ものは mitochondria であると言う、私の観察において は, 結禁後24時間前後で, Novikoff が認めたと同様な Iysosome 様構造の空胞を証した. しかし, その数も大 きさも両側尿管結杽群に比し, 比較にならない程度軽微 なものであつた。平井 ${ }^{201}$ は系球体の变化を見ているが, 結禁後 $3 \sim 4$ 週間までは変化なく, その後に系球体上皮 細胞内に mitochondoria の変性によると思われる空胞形 成 masangium 細胞の肥大と増殖, foot process の融合 を見たという，結紮後24時間值迄の私の観察では, 糸球 体には何等特記すべき変化は見られなかつた。

3. 両側尿管結紮腎について

i) 系球体について

両側尿管結禁腎の系球体に見られる変化は, 光顕的に はボウマン裴の軽度拡張と, 尿腔中に円形の有形成分及 び toluidine blue で濃染する小顆粒（主として尿細管 主部への移行部附近）の認められることであるが，時に 赤血球の存在を証することがある. 電䫓的には, 結禁後 24時間目頃より $1 \sim 2 \mu$ の電子密度の低い無構造の空胞 を認め，これは更に時間を経るとともに増大し，8〜9 $\mu$ の巨大空胞となり, 内部に泡の様な空胞を $2 \sim 3$ 認め る場合もある. 又, この空胞が上皮細胞と遊離して尿腔 中に存在する所見も得られたが，これが上皮細胞から完
全に遊離しているものか，それとも，切片の切れ具合で 遊離しているように見えているかは区別出来ない，乙か し，こうした一見遊離しているょうに見光る像が他にす 多く観察される点から，この所見は上皮細胞内に形成さ れた空胞が，細胞膜をかぶつたまま尿腔中に突出し，や がて上皮細胞との連絡がたたれ，尿腔に遊離し，細胞 としての機能を失つてしまつた一つの有形成分として観 察されるものであるという可能性を信ずるものである. 又，その空胞をとりまく限界膜は一種の膜で形成される 場所もあるが，明らかに二重膜で形成される場合が多 い.この二重膜の外側膜は上皮細胞の細胞膜であり, 内 側のそれは空胞形成による膜であると考兄られる。一重 膜で形成される架胞も附図の如く右方部は二重膜になつ て和り，外側膜は明らかに上皮細胞膜飞移行しているの が見られる. Farquhar et $\mathrm{al}^{91}$ は臨床上亜急性系球体腎 炎と診断された症例を検討し, 系球体上皮細胞内に多数 の大きな空胞出現を, 又, ネフローゼ50)の際にもそれを 認めている。しかし，それとともに foot process の消 失, 隔合などの大きな病変をみている. 大島 ${ }^{301313221}$ は系 球体腎炎, ネフローゼ, 腎硬化症などを, 藤崎 ${ }^{11}$, 坂口 39) らは糖尿病性腎症を含め同様 な疾患を, Folli ${ }^{123}$, 竹 内 ${ }^{44}$ は nephrotic syndromを，その他多くの人々によ り種々な傷害腎の糸球体が観察もれているが, 上皮細胞 内の巨大空胞形成のみが病変となるような疾患はなく, それとともに foot process や基底膜, 内皮細胞及び mesangium 細胞などの変化の合併を観察している，本実 験では上皮細胞内の巨大空胞形成以外には変化は認めら れなかつた。他方, 近位尿細管々腔内にも, その限界膜 は二重膜ではないが，同様の円形の有形成分を認めてい る (附図20，21参照).したがつて，こうした糸球体上皮 細胞内の空胞形成も尿管上皮細胞に見られると同様な機 転で生ずるものではないかと考兄られる，又，系球体の その他の部分は結紮後 $24 \sim 48$ 時間の如き極めて短期間で は，病変は起りにくいものと思われる，又，程度の差は あれ，片側及び両側尿管結禁群ともに，尿腔及び尿細管 腔に赤血球を見，その系球体起源を推測するも，内皮細 胞の pore, 基底膜には変化を見ず，その発生機転に関し ては不明である。

ii）尿細管について

両側尿管結紮群に見られた尿細管々腔の開大，近位尿 細管上皮の腫脹, 突出, 時にその破壊像については, 大 沢 ${ }^{32}$ は急性系球体腎炎及び慢性腎炎に打いても程度の激 しい場合には細胞原形質の減少，刷子縁の離断とそれに 
よる内容の逸脱を屡々見, 更に高度になれば基底膜のみ が管腔に露出し, 細胞部位の判定し難い時すらあるとい 万.私の観察でも附図24の如く, それに似た像が見られ た. Anderson and Recant ${ }^{11}$ は 7 日間連続蛋白注入を 行なつたラットで，近位尿細管上皮の microvilli の消 失を観察した。 Caulfield and Trump ${ }^{6)}$ は高調ブドー 糖静注後 4 分目に, 光顕的に管腔の著明な拡張と細胞先 端部の突出を見，これを電顕的にも認めている. 矢野 ${ }^{499}$ は犬を用い副甲状腺ホルモン長期投与後, 管腔開犬, 細 胞突出を見，その像は附図20と全く類似している. 関 ${ }^{41)}$ も同様に副甲状腺ホルモン投与ラットで, 光顕及び電顕 で同様の所見を得たと報告した。たＦＦjibayashi ${ }^{13)}$ は パラアミノ馬尿酸ソーダを静注した鬼で刷子縁の乱れ， 消失，及び変性した mitochondria を管腔内に認めてい る. 又 microvilli 直下の空胞が吸収機能に関与するこ とが知られているが, Anderson and Recant ${ }^{1)}$, Canlfield and Trump ${ }^{6)}$, Fujibayashi ${ }^{13)}$ ，矢野 ${ }^{49}$ 等もこの空胞の増 加を観察している. Farquhar et $\mathrm{al}^{9)}$ もネフローゼの 症例でこれを見, Rollhäuser ${ }^{37)}$ は perabrodil 及び phenol-red 静注後に basal intussusception の離開とと もに, この空腔增加を観察し, 分泌機能の点から両者 の関連を考兄ている。田中 ${ }^{42}$ は含糖鉄フェジンを静注 したラットで，尿細管上皮におけるフェジンの取り込 み，およびその細胞内辺処理過程を見ているが，その際 microvilli 直下の空胞はそれ程大きさは変らないが数 の増加を認めている. 大沢 ${ }^{32}$ は疾患別, 又病状によつて この空胞の状態が異なることを表示しているが，上皮細 胞の変化が激しくなれば空胞出現が少なくなることを示 している。私の観察も，“結紮後増加を来たした microvilli 直下の空胞は, lysosome 様構造の空胞による, 細 胞内変化が激しくなるにつれ, 目立たぬ存在となり, 反 つて，次第に減少を示した。即ち，矢野 ${ }^{49}$ は上皮細胞の 管腔内突出を単に变性像だけではなく, 分泌又は吸収と いう機能態度を示すものとも考えられるとしたが，私は 上皮細胞管腔側の腫脹, 突出, microvilli の消失は変性 の初期像で, 細胞变化が軽度のらちは吸収機能も高まる が, 次第に変性が激しくなるにつれて, その機能も悪く なり, 最後には細胞の崩壊が起きるのではないかと推測 した。な抽，光顕的に系球体の尿腔（主として尿細管主 部への移行部）に toluidine blue で濃染する小顆粒を みたこと，及び電顕的にヘンレ氏係蹄以下の尿細管々腔 内に円形の有形成分や，変性した mitochondria を観察 したことは，こうした近位尿細管上皮の崩壊に基づくも
のであると考えた．

次に近位尿細管上皮細胞内に現われた lysosome 様構 造の空胞出現に関しては, Farquhar ${ }^{9)}$ はネフローゼ で, Breuer and Eguren ${ }^{5)}$ は人のへモグロビン及び卵 白を負荷したマウスでこれを観察している. 又, Novicoff の実験的水腎症の場合も, 内部に殆ど正常に近い mitochondriaや変性した mitochondria によつて生じた と思われるミェリン様構造物を含んだ同様構造を観察 し, 結紮後 6 時間目に結紮を解除し, 光顕的に酸フォス ファターゼの検出を行つた所, 変性のない部分は正常反 応を示すが，起した上皮細胞には大きな不規則な陽性物 質がみられたといら。しかし, いずれの場合も, 本実験 に見られたごとき, 細胞全体にわたるような著明な変化 は認めていない. Janigan et $\mathrm{al}^{22)}$ は sucrose 投与時の ラット腎で大きな空胞構造を認め, これとRhodin によ り big granules と呼ばれた小体や, Novicoff の述べ た酸フォスファターゼ顆粒との移行型を認めた。 しか も, 更に病変が進めばこの空胞構造の融合が起り, mitochondria RNP 粒子, ミェリン様構造を認めると報告 した. 間 ${ }^{199}$ も sucrose 投与腎を電顕的及び組織化学的に 検索し，全く同様の所見を観察した。 そして，これは生 理的に酸フォスファターゼ活性の認められない microvilli 直下の空胞が拡大し, 活性を示す lysosome 様性格 のものになると報告した。 こうした sucrose 投与時の所 見は，私の行つた両側尿管結紮腎の所見と全く同じであ る. 私も光顕的に両側尿管結禁後 24 時間目の腎で酸性フ オスフアターゼ検出を行つたが，附図10，11，12亿示す 如く, 近位尿細管上皮細胞内にそれを証明した。しかも ，附図12に見よれるように，かなり大きな陽性物質が見 られ，一見正常に比しその増加を思わせるが，この所見 のみから活性が上昇しているとは断定出来ない。しかし 電顕的に正常の lysosome が殆ど観察されなかつたにも 拘らず, 光顕的に活性が示されるのは lysosome 様構造 の空胞が lysosome から変化したものであると断定して も無理はないものと考觉る. lysosome の発生に関して は, pinocytosisにより phagosome を経て lysosome が形成されるといら考方方と, Golgi 装置が変化して lysosomeが形成されるといら考方方がある。両側尿管結 杽腎でも附図34のよらな像が見られ，これらは前者の考 え方を示唆するものと思われるが，こうした像が特に多 く見られることなく，一方 Golgi 装置から lysome へ の移行を思わせるような像も観察されていない，従つ て, 細胞内に見られた変化は, 既存の lysosome が何等 
かの原因によつて変化をおこし，内部に存在する酵素が 活性化されて mitochondoria を始め細胞内容物が融解 されたものではないかと思う。

$J_{\text {Janigan }}{ }^{22}$ も同様に, lysosome に変化が执こり，加 水分解酵素が細胞内変化を起こすのではないかという. Wilmer ${ }^{48)}$ は光顕的に鬼の sucrose 負荷腎をみ, 細胞内 浸透圧の変化により生ずるのではないかと推論した。

lysosome に変化を生ぜしめる因子に就いては，あく まで推論の域を出ず，それを証明することは難しいと $\mathrm{Janigan}^{22)}$ は述べている。一般に腎不全の際には血液残 余窒素の增量, 血浆又は血清 $\mathrm{Na}, \mathrm{Cl}, \mathrm{Ca}$ の低下， $\mathrm{K}, \mathrm{P}$ の上昇, 代謝性アチドージス, その他の現象が起り, 臨 床的には尿毒症といら症候群が現われるわけであるが， 私は単に血液残余䇪素及び血清電解質のごく一部を検索 したのみで，血液残余窒素の増量と血清 $\mathrm{K}$ 值の上昇を認 めた以外変化なく, 私も如何なる因子が lysosome に変 化を与光るかを推論することは全く不可能であつた。し かし，片側及び両側尿管結紮腎に和いて，各腎の受ける 機械的傷害は同じであるにも拘らず，後者ではかなり違 つた組織像を示したことは，広い意味での尿毒症といら 条件によつて生じた結果であり，その主役をなすものは lysosome にあろうと推断した。腎間質に関ししは Goloor and Neiditsch-Halff がラットの髄質を電顕で観察 して括り，間質細胞は星状をしていて，周团尿細管及び 毛細血管の基底膜には細胞体の padycyte で接すると云 万。従つて附図33に見られる間質は対照群に比してやや 広いようではあつたがそれが浮腫のような病的状態を示 するのであるかどうかは断定出来ない。

\section{$\mathbf{V}$ 結 語}

ラットの両側尿管結紮を行い急性尿毒症を発生させ, その腎臓に Mausbach et al らの滴下固定法を行ない, 光顕並びに電顕にて観察し，次の結論を得た。

1）滴下固定法によるオスミウム酸の浸透速度は，一

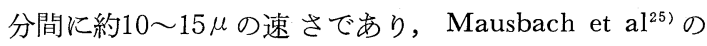

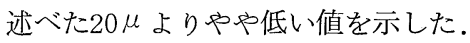

2）正常腎に执いて，滴下固定法で固定される部位の 尿細管々腔は Mausbach et $\mathrm{al}^{24)}$ が示した様に，全て が開存するわけでなく，逆に閉鎖しているものが多く観 察もれた。

3）滴下固定法と浸漬固定法の両者で固定される中間 の部位では，片側及び両側尿管結紮群ともに，近位尿細 管の上皮細胞内に著明な空胞が出現したが，私は固定の 際に生ずる人工的変化であると考元た。
4）人工的変化で生ずる空胞と lysosome 様構造の空 胞とは，光顕的には明確に区別出来ないか，電顕的に は，前者は basal intussusception の開大によつて生ず る空胞であり，内部は殆んど無構造で後者とは明らかに 区別出来る.

5）片側尿管結禁群の尿細管々腔も一部開大を示す が，両側尿管結禁群の方がより顕著である.

6）糸球体毛細血管及び尿細管周囲の血管内の赤血球 密度は, 滴下及び浸漬固定法の相違により程度が異り, 前者で固定された部位はその密度が高かつた。

7）両側尿管結紮群では，糸球体上皮細胞内に巨大学 胞の発現がみられ，やがてこれが尿㬵内に遊離するもの と推測される様な所見を観察した。 又，時に赤血球を尿 腔内に認めたが，その他の構造には特別変化を認めなか つた。

8）両側尿管結紮群の近位尿細管の microvilli 直下 に見られる空胞は著明に増加した。

9）両側尿管結紮群の近位尿細管の上皮細胞は，管腔 側の腫脹, 細胞全体の管腔内突出, 時に細胞の破壊像が 観察された。片側尿管結紮群にも腫脹及び管腔内突出が 軽度には見られた。

10）両側尿管結紮群の近位尿細管の上皮細胞内には, lysosome 様構造の空胞が著明に出現し，この空胞は結 紫後の時間に比例して増大し, 最後には細胞質内部は殆 ぞこの像のみで占められる．この所見は光顕的空胞变性 に一致する。片側尿管結紮群にも同様の空胞を認めたが 非常に軽微なものであつた。

11）光顕的に Gomori 氏法 ${ }^{15}$ とより酸性フォスフアタ 一ゼの検出を行つた所, 両側尿管結紮群の近位尿細管の 上皮細胞内にそれを証明し得た。よつて lysosome 様構 造の空胞は, lysosome が変化したものであると推断し た。

12）片側及び両側尿管結禁の両群とも，ヘンレ氏保蹄 以下の尿細管の上皮細胞には変化は認められなかつた が，管腔内に赤血球及び円形の有形成分を認めた。 しか し，この所見は両側尿管結毞群の方がより高度であり， 時には变形した mitochondria などまでが管腔内に観察 された。その発現機序は，近位尿細管の上皮細胞の管腔 内突出，破壊によるもの之推測される。

13）両側尿管結禁群では糸球体及び尿細管周囲の間質 が一部離開する傾向が見られた。

14）片側尿管結紮群の腎病態を更に強度に修飾した両 側尿管結紮群の系球体及び尿細管の病態は，広義の尿毒 
図

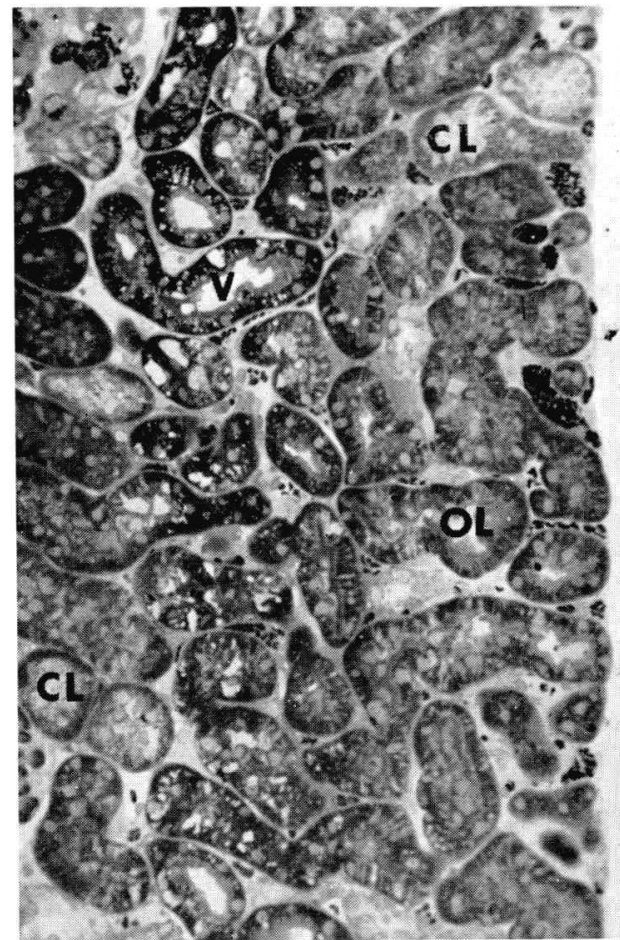

沙

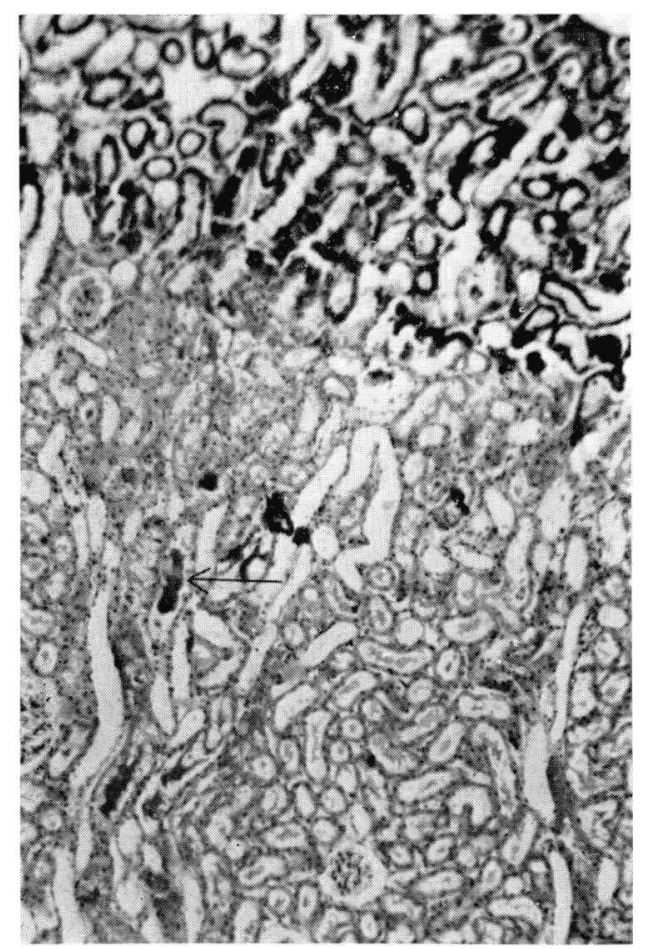

図

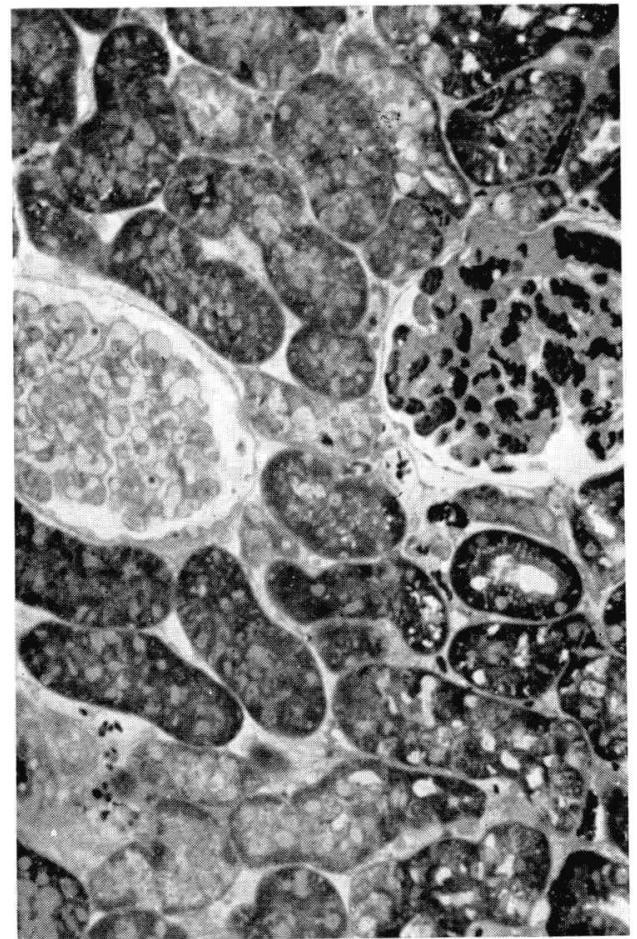

\section{闵 4}

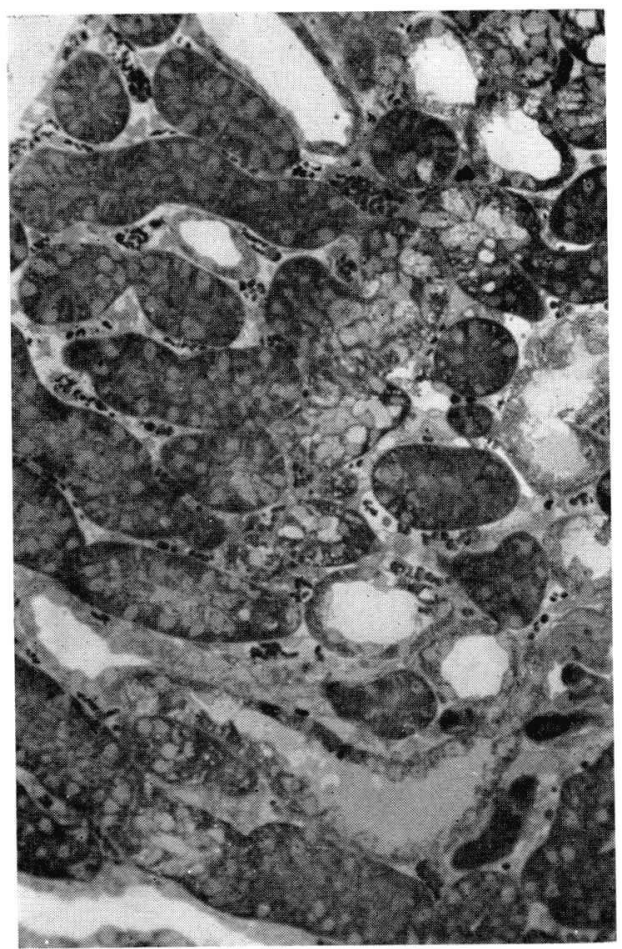


図 5

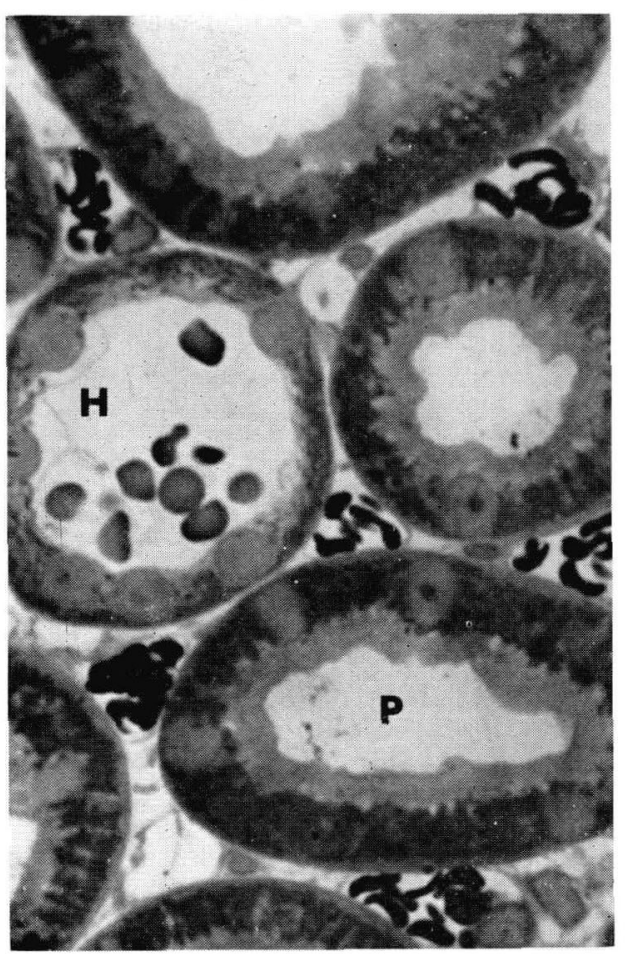

図 7

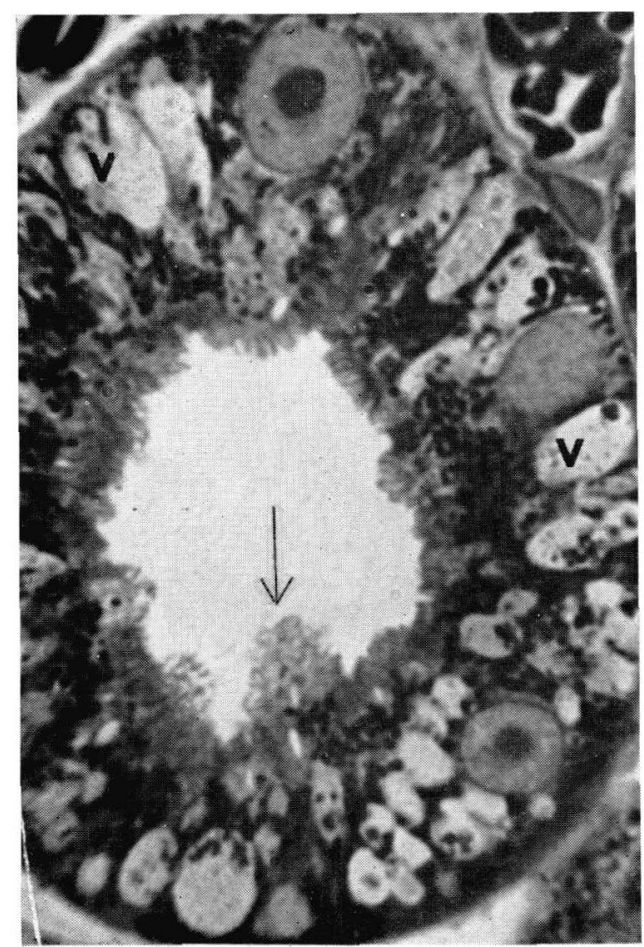

図

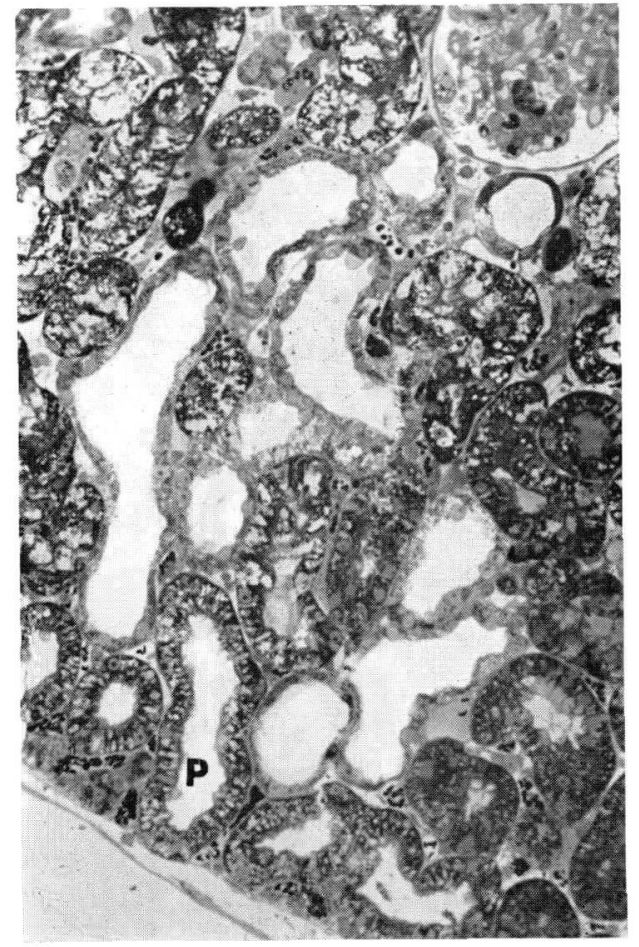

図

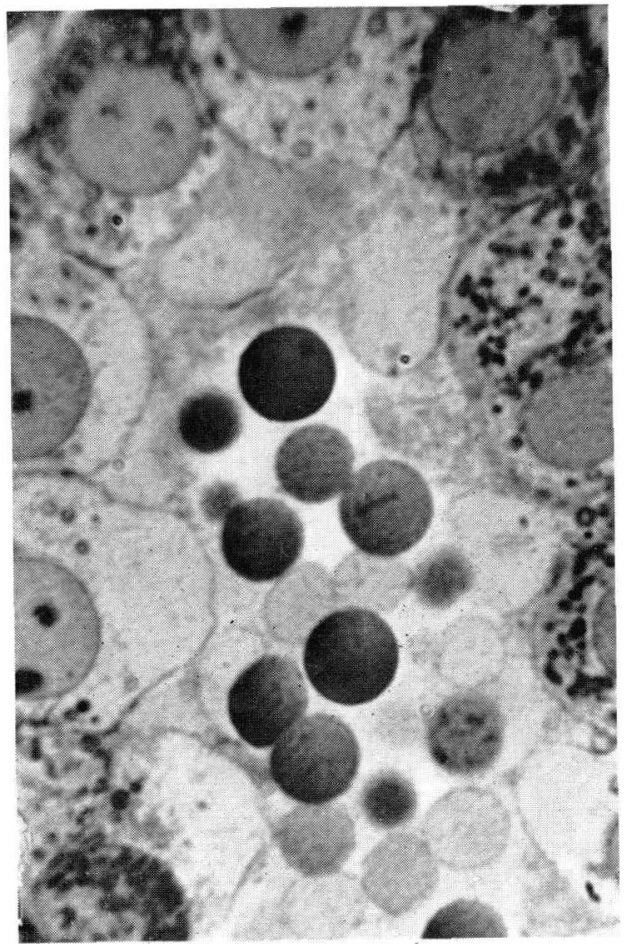


図 9

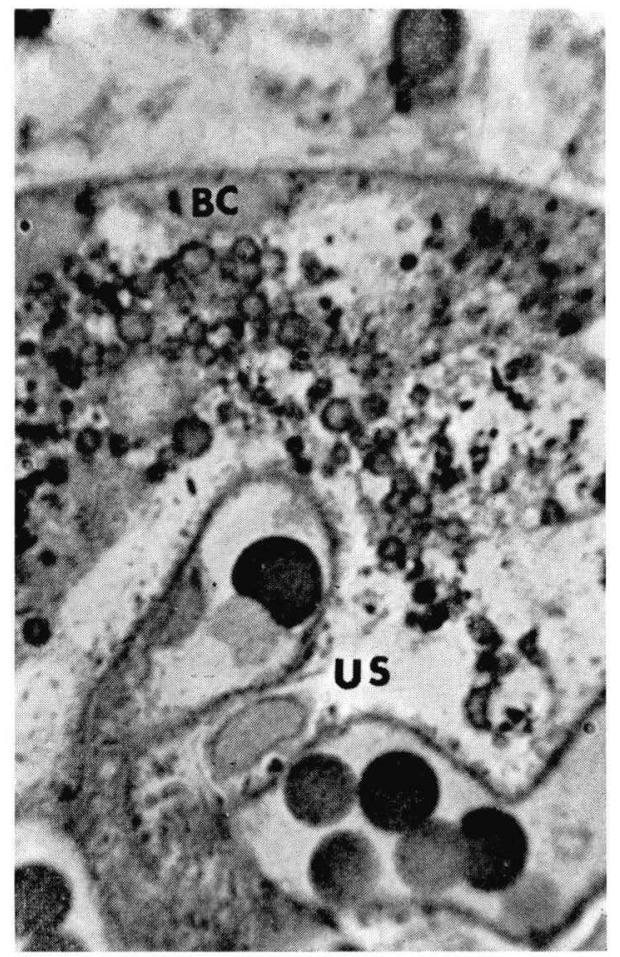

図 11

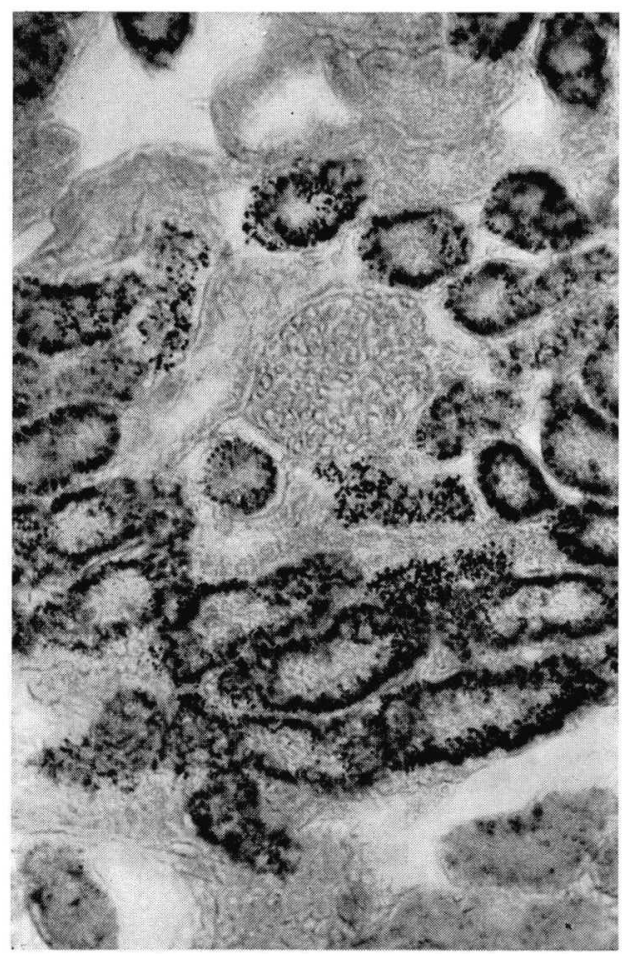

図

10

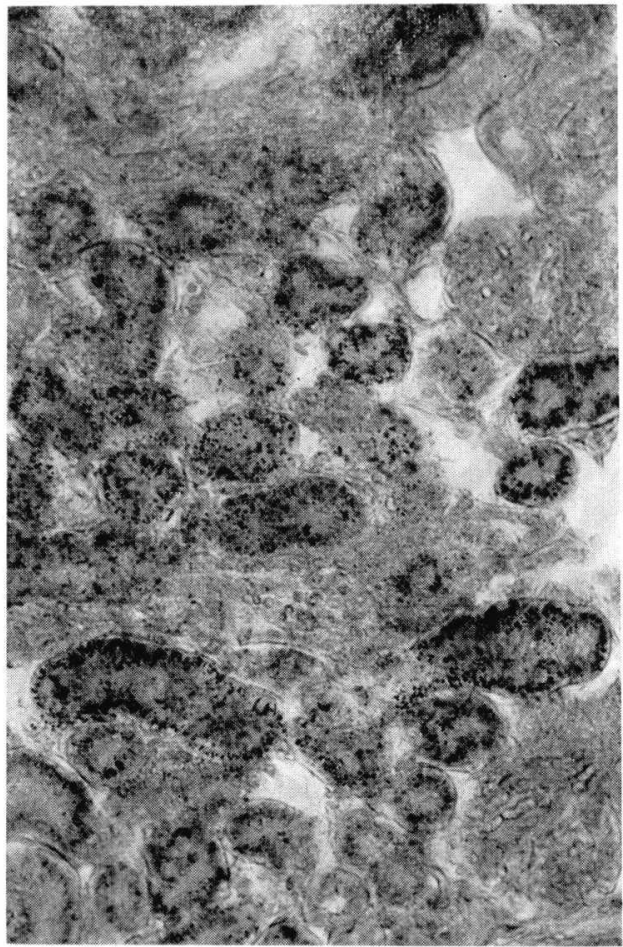

図 12
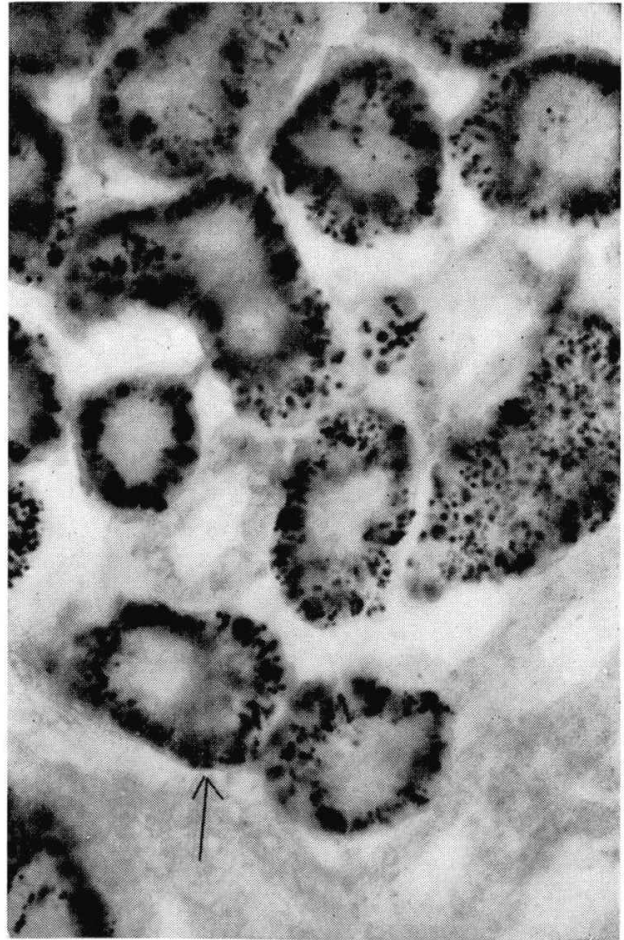
図 13

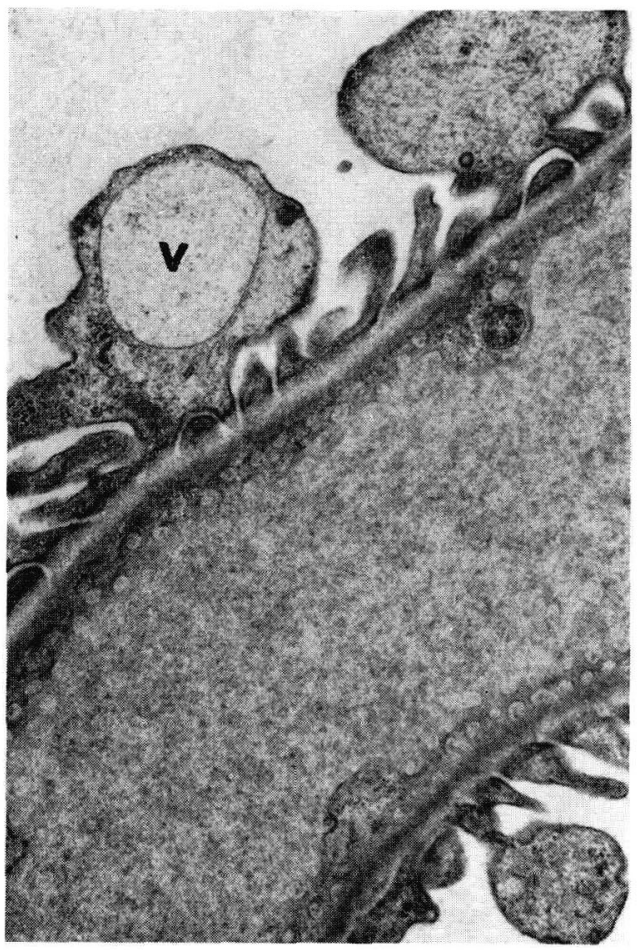

図 15

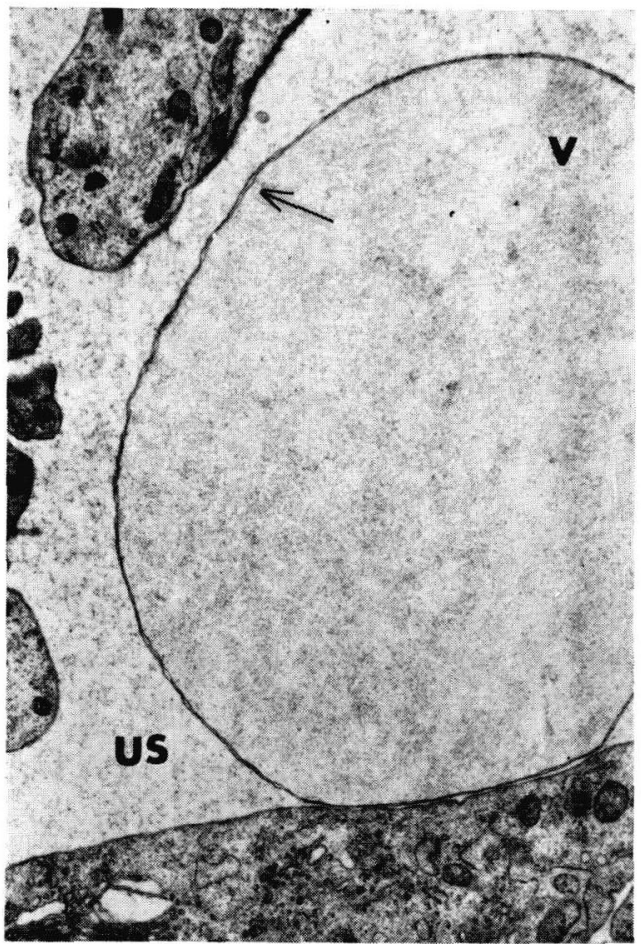

図 14

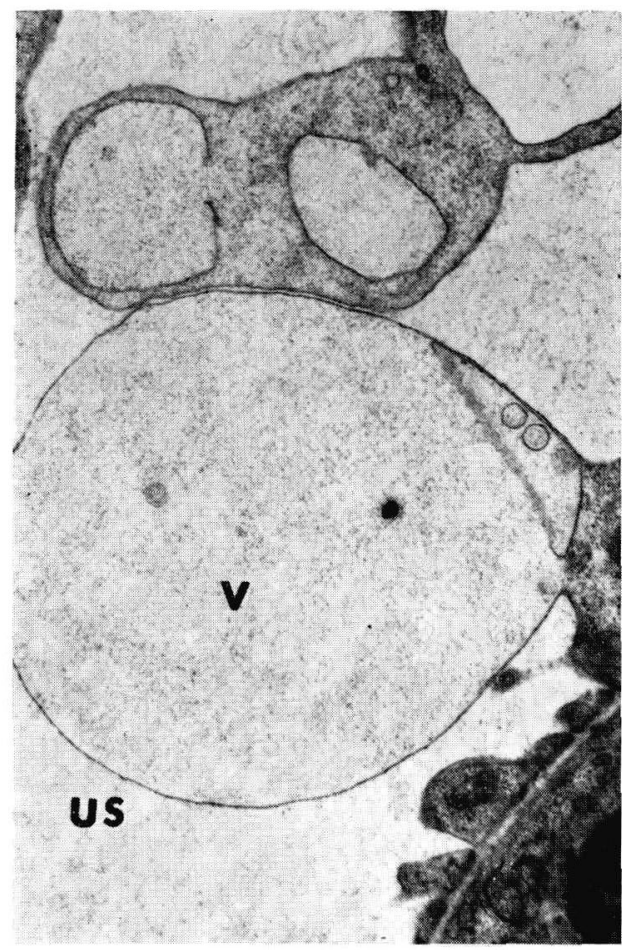

図 16

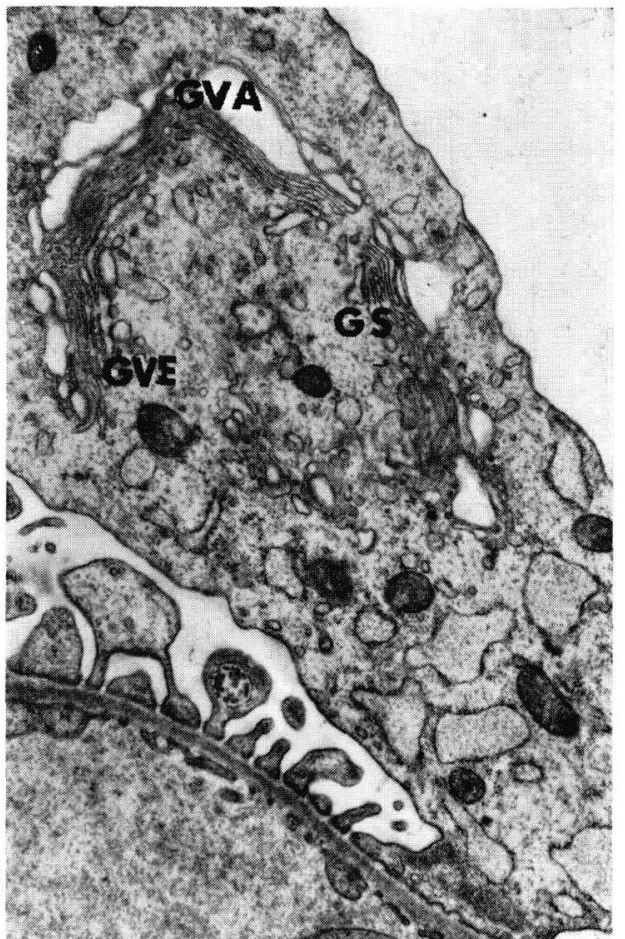


因 17

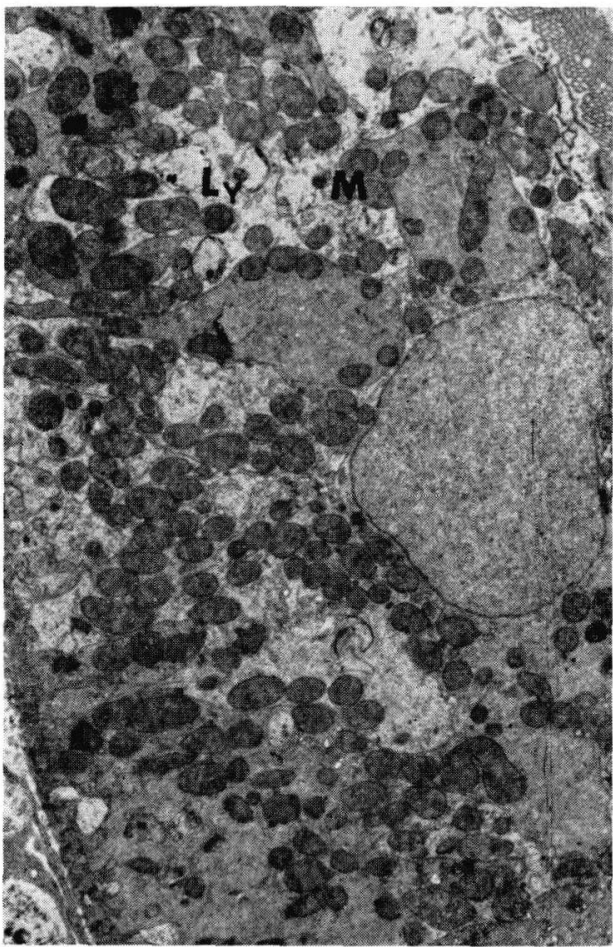

図

19

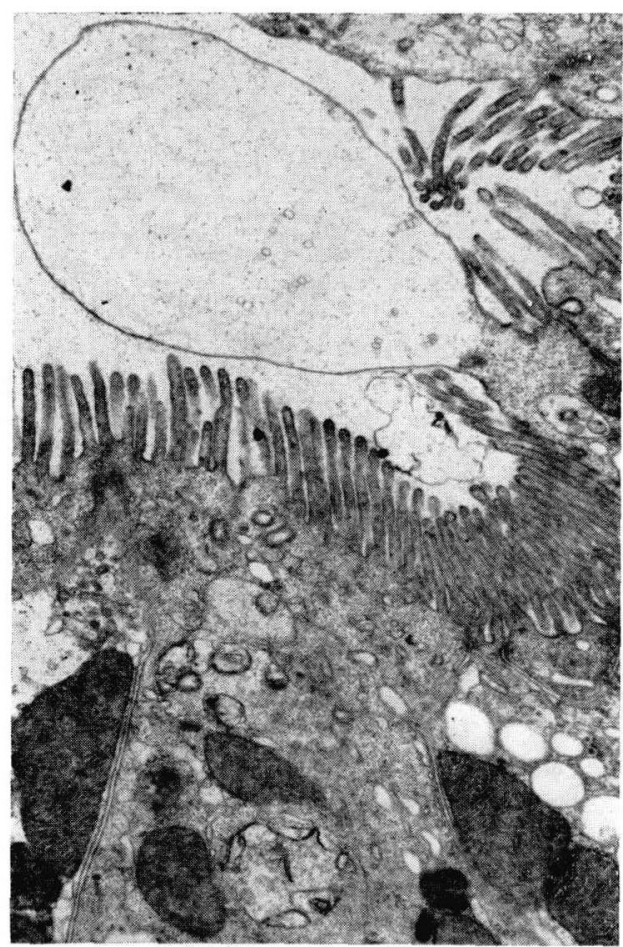

図

18

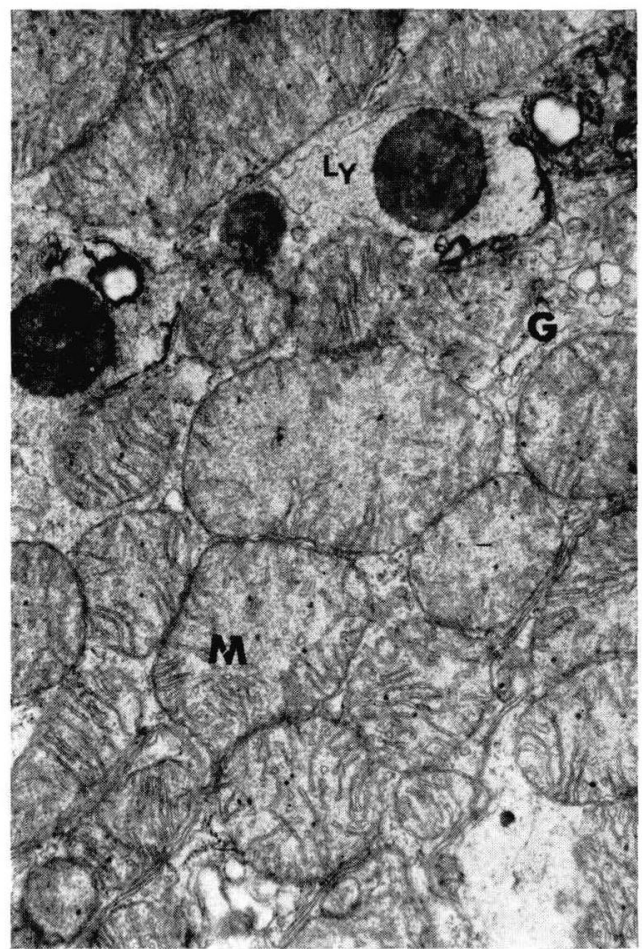

四

20

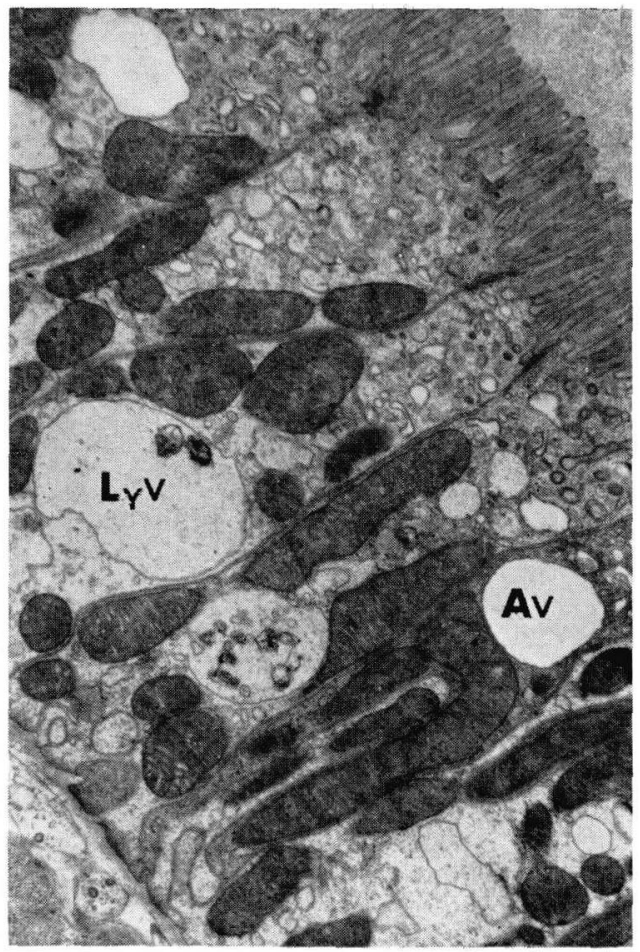



21

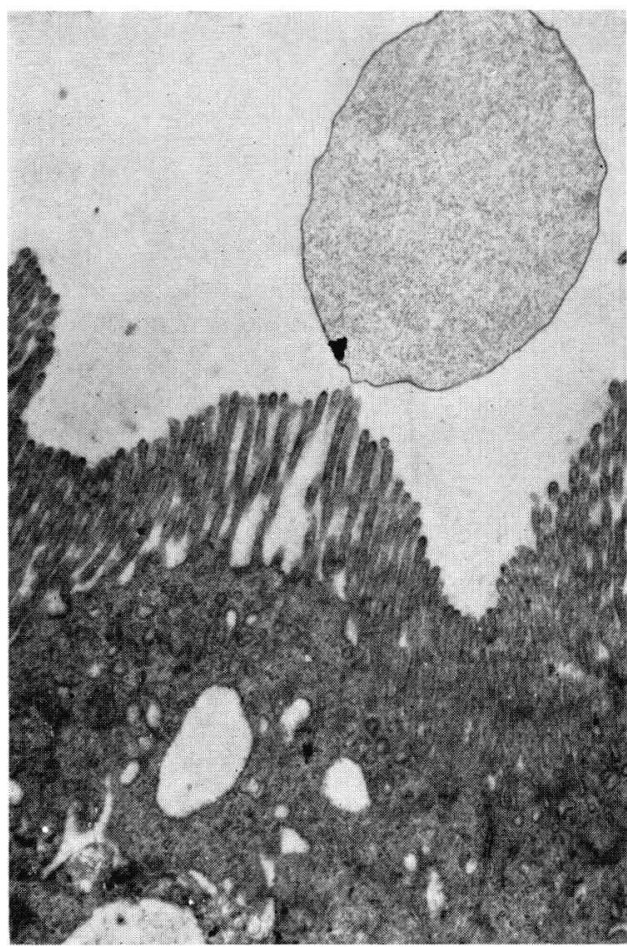

図 23

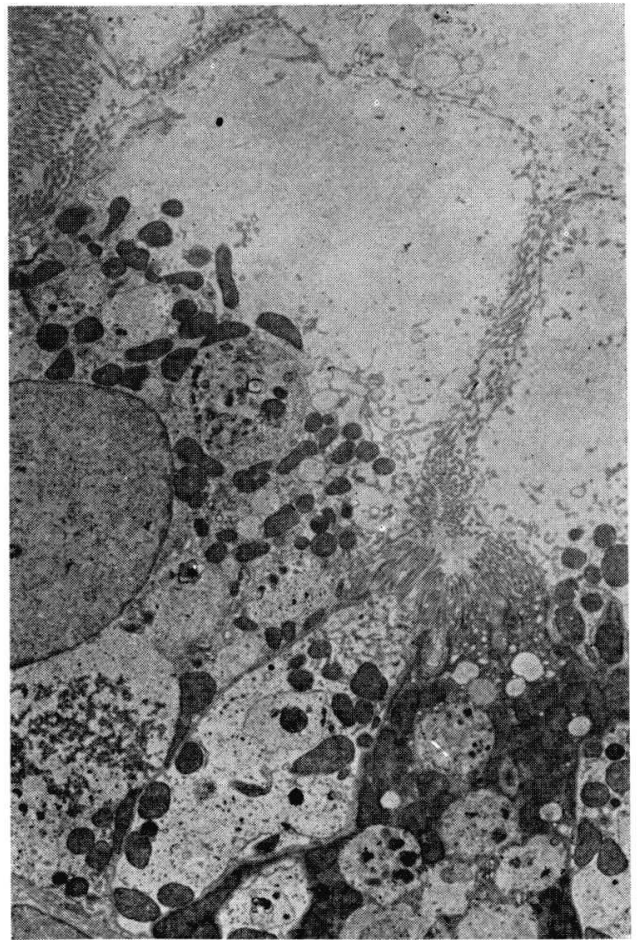

図 22

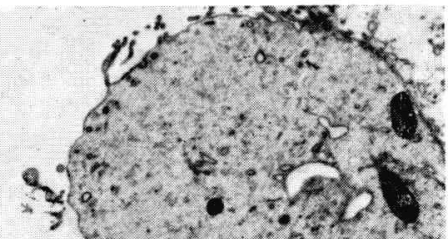

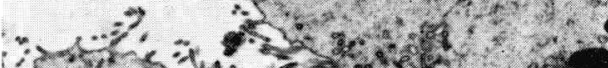

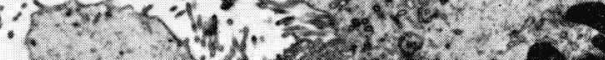

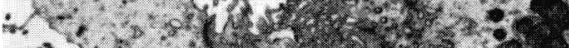

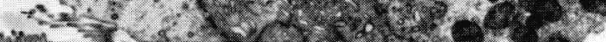

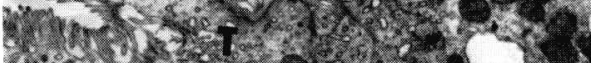

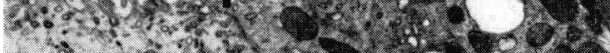
Lin:

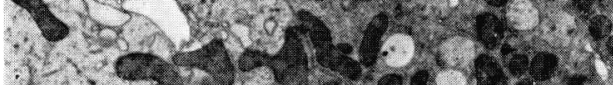

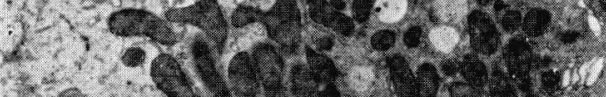

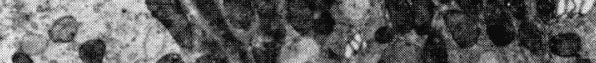

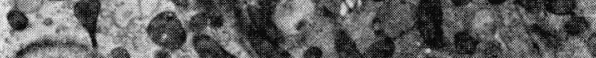

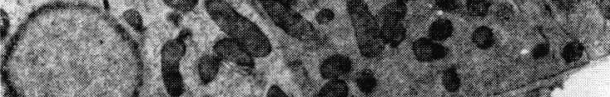

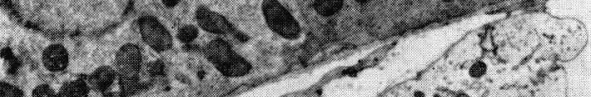

図 24

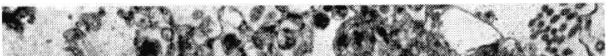

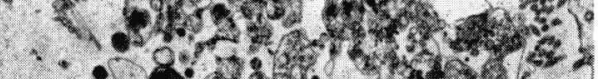

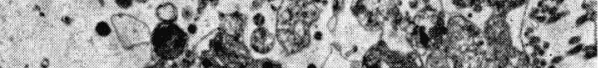

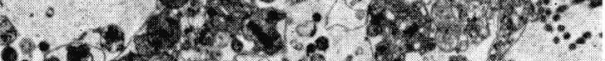
13.

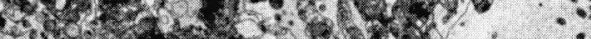

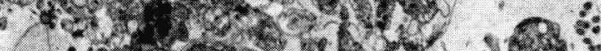

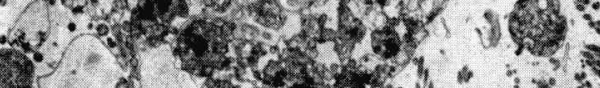

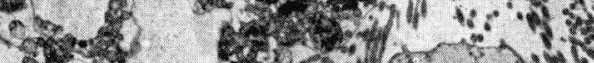

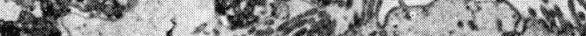

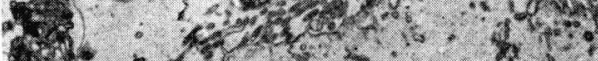

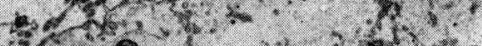

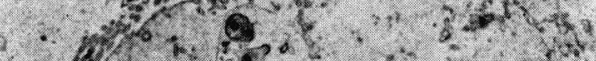

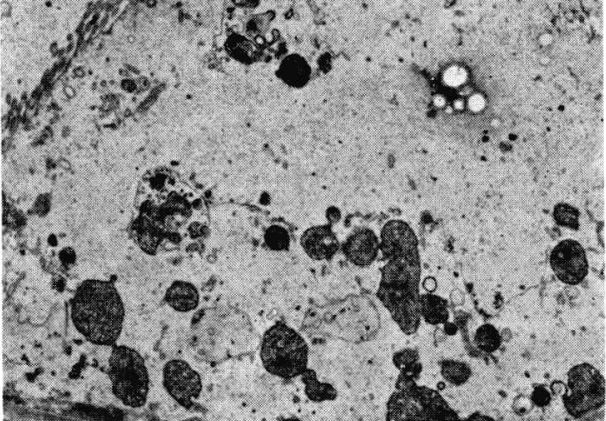


図 25

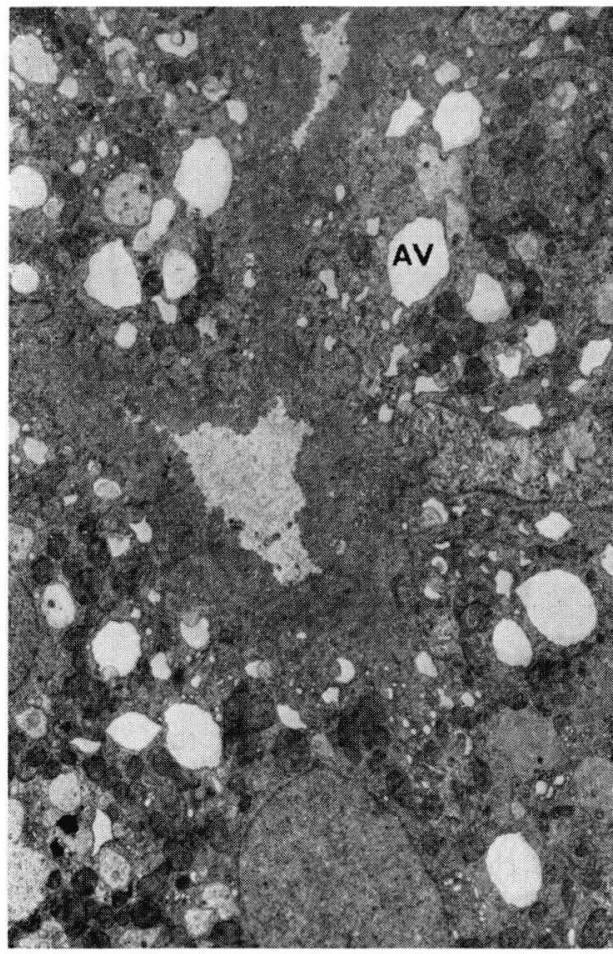

図 27

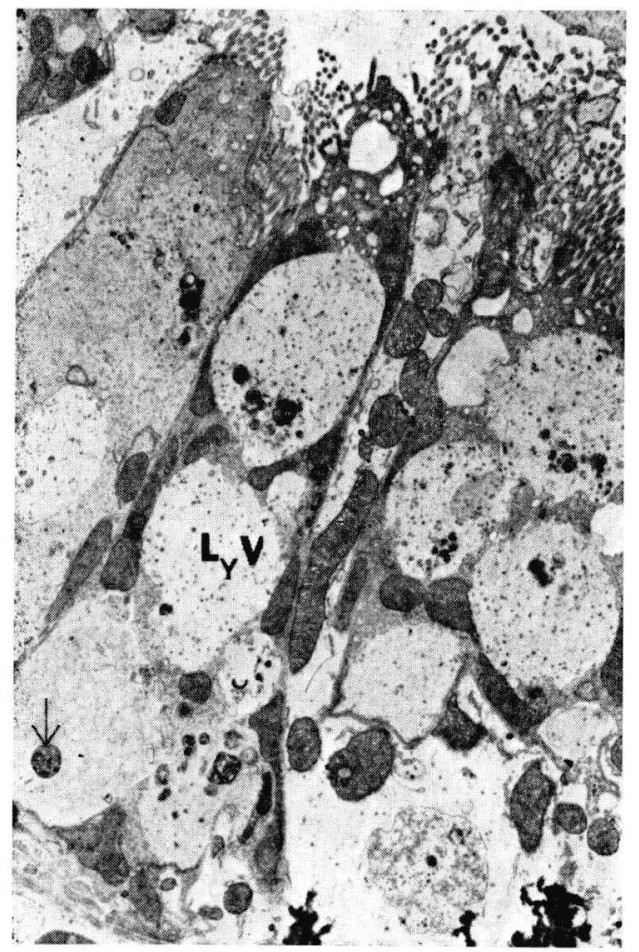

圀

26

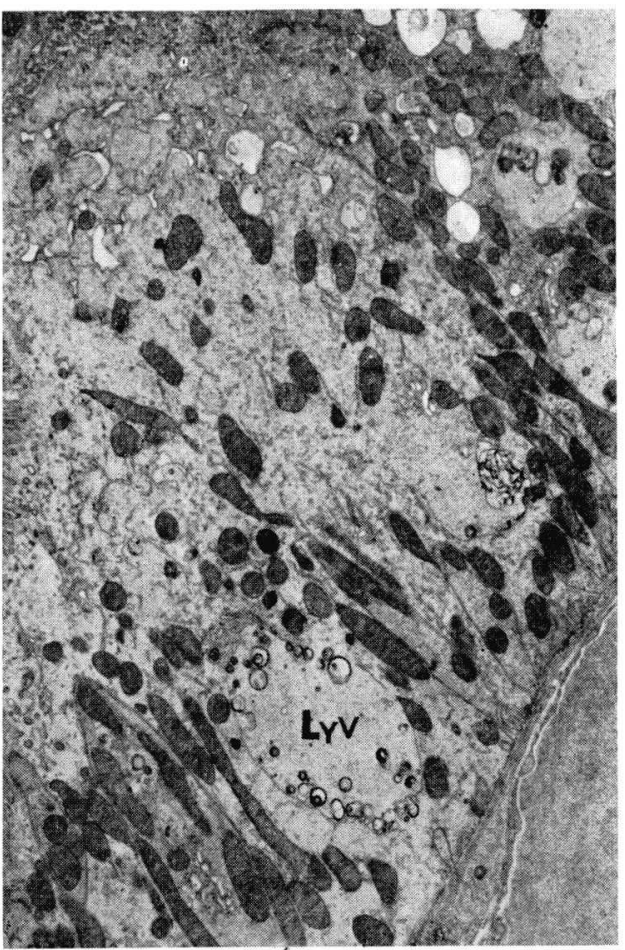

図 28

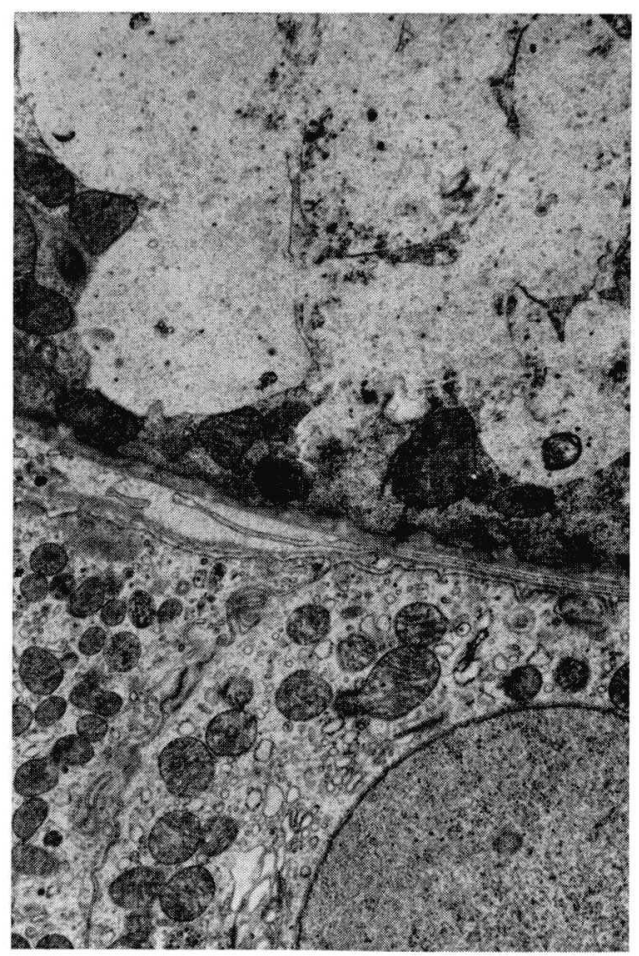


図

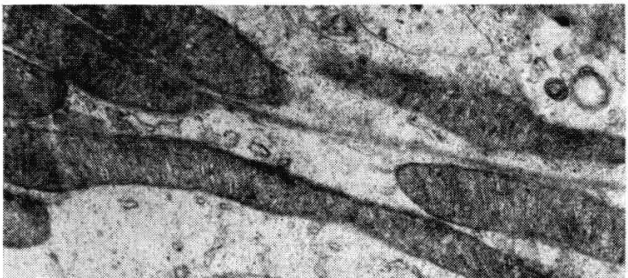

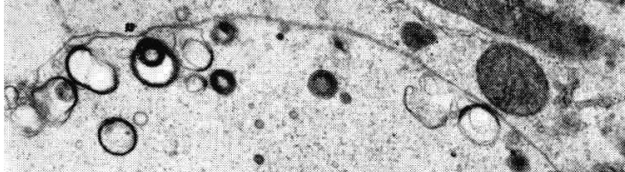
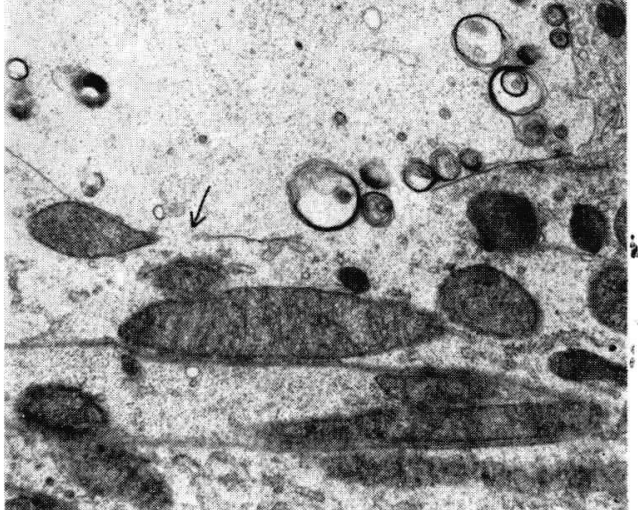

成 31

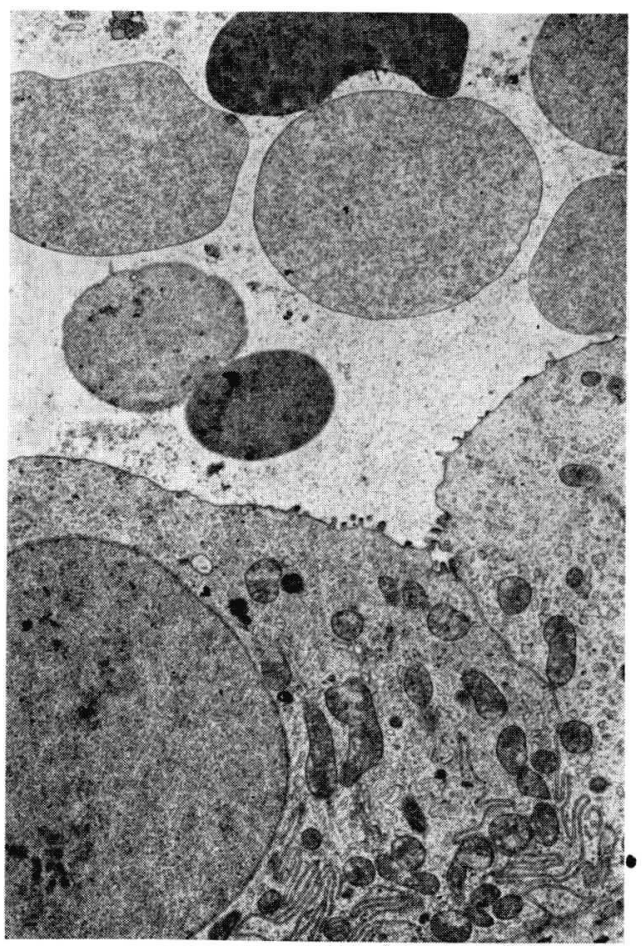

図 30

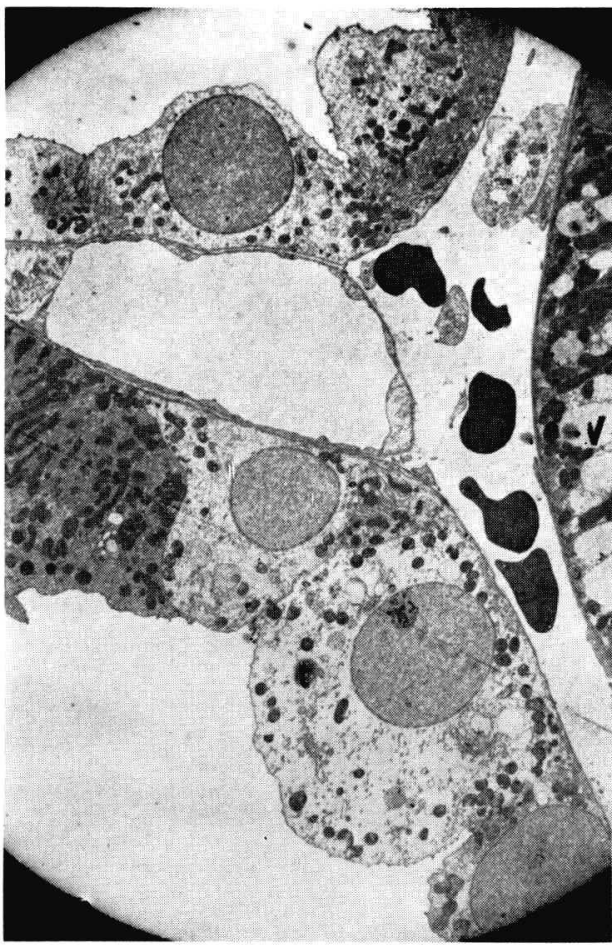

図 32

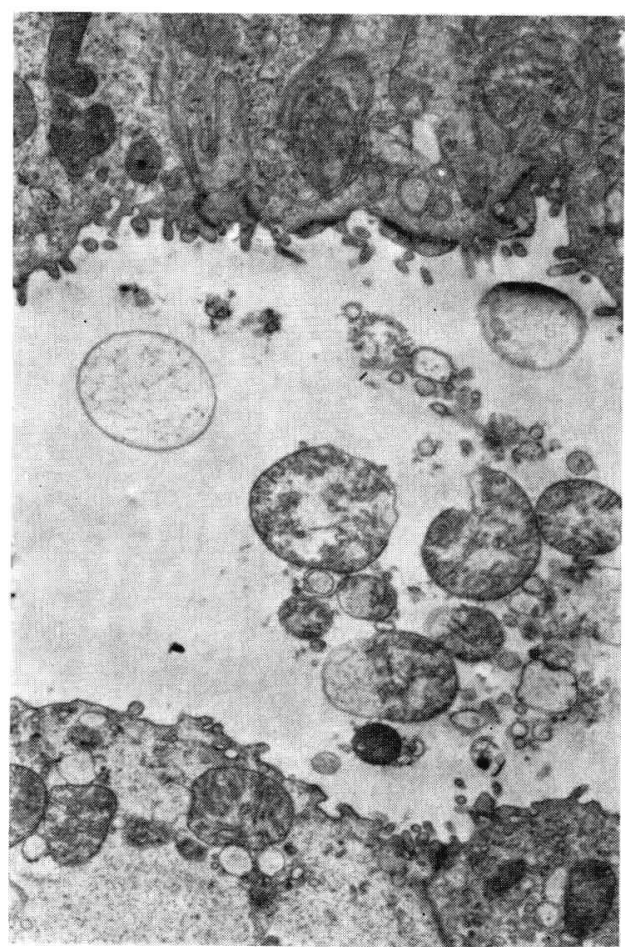


図

33

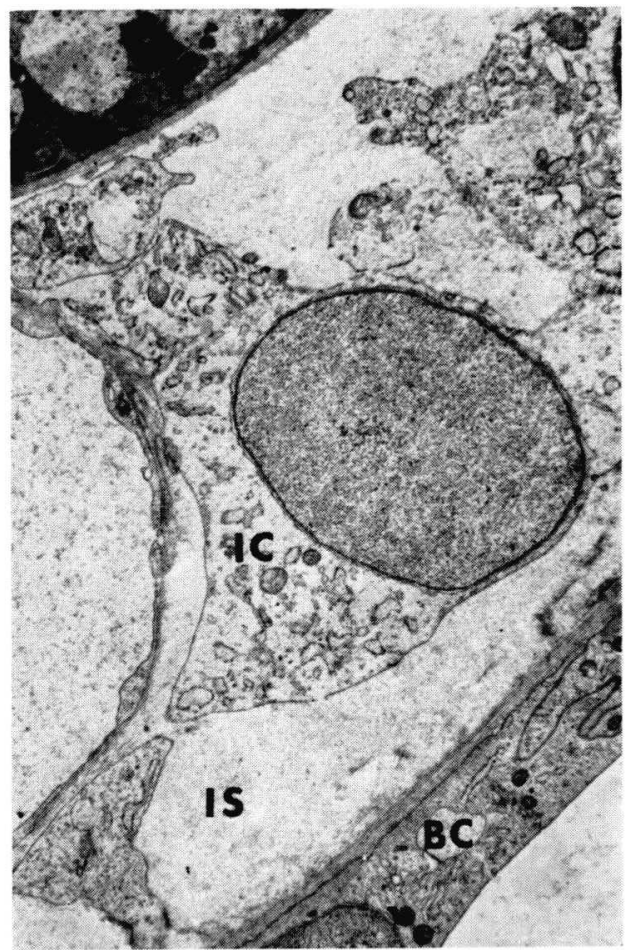

図 35

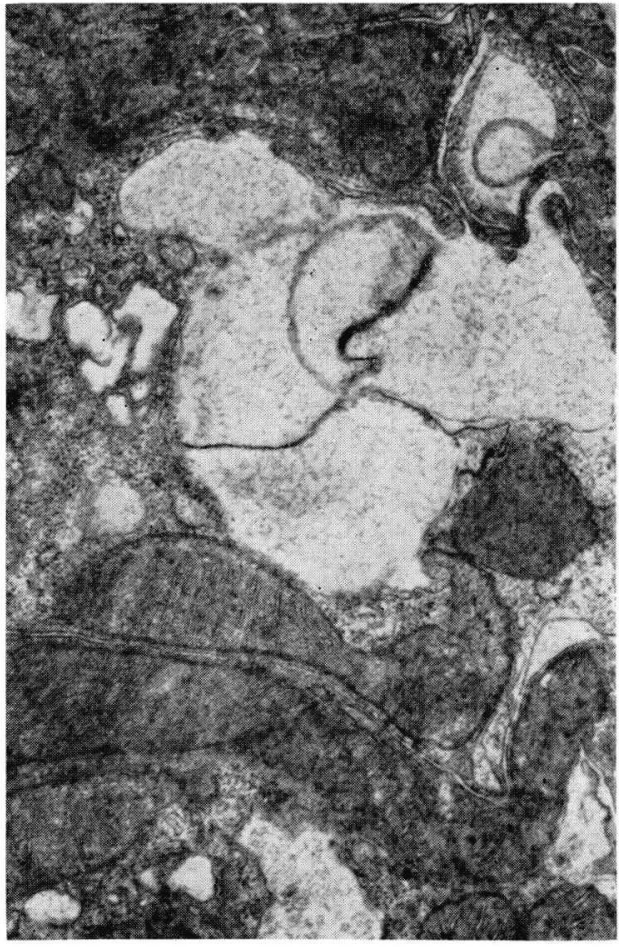

饶

34

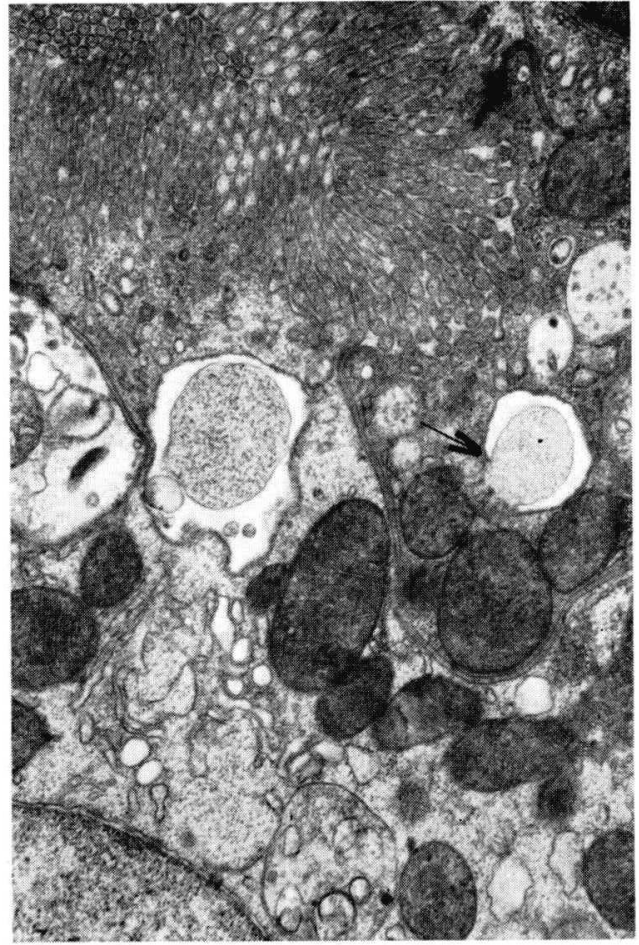

図 36

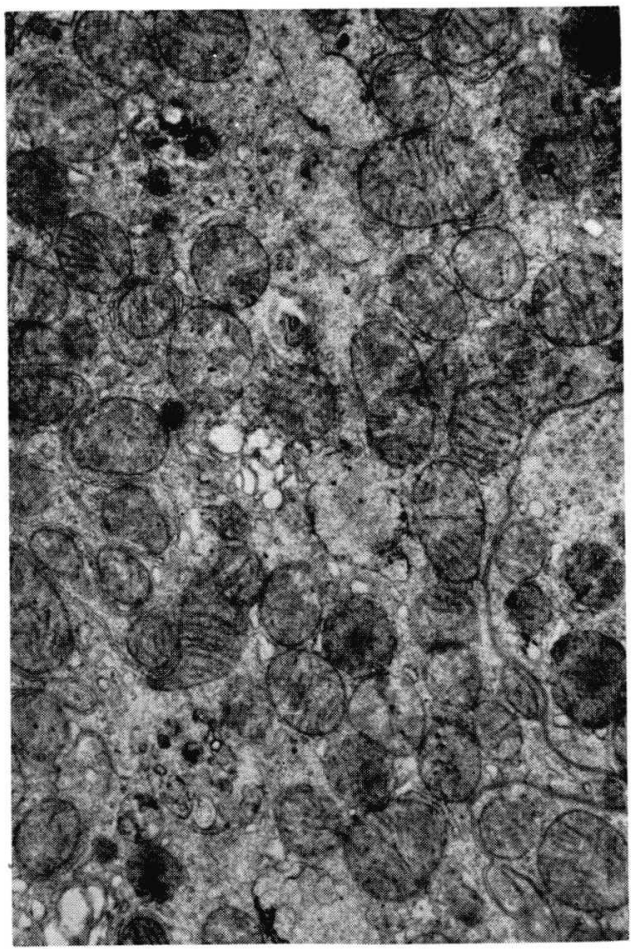


症に基づく変化と推測した。

稿を終るに臨み, 御指導御校閲を賜つた百瀬剛一教授 に深謝するとともに，本研究の光顕的㭘索に適切なる御 助言を賜つた本学第一病理学教室滝沢趆次郎教授及び電 顥の使用に便宜をあたえられた第二解剖学教室野中俊郎 前教授, 又本研究の電顐的検討に終始御愳篤なる御教示
をいたら゙いた第二解剖学教室永野俊雄教授並びに技術面 での多大の御助力を下さつた嗆代修氏に謹んで御礼を申 し上げます。

な拝, 論文の要旨は第54回泌尿器科学会総会に招いて 発表した。

\section{附 図 説 明}

1）正常腎の光顕像

腎表面（右方）より 3〜4 尿細管直径の部位では管腔は開大する場合（OL ）と閉鎖する場合（C L ）とが あるが，後者の方がずつと多い，それに続く中間部の上皮細胞内には空胞形成 $(\mathrm{V})$ を認める。ブロック深部 （左方）の管腔は全て閉鎖している。（（OL)、オスミウム酸固定, epon 包埋, toluidine blue 染色. $\times 200$

2) 正常腎の光顕像

系球体毛細血管内の赤血球密度は部位によって異なる。左方は深部，右方は中間部の系球体，オスミウム酸 固定. epon 包埋, toluidine blue 染色 $\times 200$

3) 正常腎の光影像 オスミウム酸一時間の滴下固定後フォルマリン固定, ペラフィン包埋, ヘマトキシリン・エオジン染色した もの. 右上方は腎表面で, 濃染しているのはオスミウム酸の浸透した部位である. 樑部の一つのネフロンに沿 つてオスミウム酸で濃染した物質がつまつている。（矢印）、オスウム酸, フォルマリン二重固定, H-E染色。 $\times 50$

4) 片側尿管結紮腎の光顕像（結禁後24時間目）

左上方は腎表面で，遠位尿細管，集合管の拡張をみる。中間部の尿細管上皮細胞内には，やはり空胞形成が

見られる。オスミウム酸固定 epon 包埋, toluidine blue 染色. $\times 200$

5) 片側尿管結禁腎の光顕像 (結禁後20時間目)

近位尿細管々腔は開大して㧍り, ヘンレ氏係蹄内には赤血球を認める。オスミゥム酸固定, epon 包埋, tol一 uidine blue 染色. $\times 800$

6) 両側尿管結紮腎の光顕像（結禁後28時間目）

左下方悭表面で, 尿細管々腔は拡張するのが多い。近位尿細管の上皮細胞の空胞変性が著明であるが, 固 定の際に生ずる空胞形成との差は明らかでらない. (附図 1,4 を参照).オスミウム酸固定, epon 包埋, toluidine blue 染色. $\times 200$

7) 両側尿管結紮腎の光顕像 (28時間目) 近位尿細管で, 刷子縁の一部が管腔内に突出して㧍り (矢印), 上皮細胞内には著明な空胞变性を認める. 又 空胞内には toluidine blue で濃染する小顆粒が見られる.オスミウム固定, epon 包埋, toluidine blue 染 色. $\times 1800$

8) 両側尿管結禁腎の光顕像（結紫後28時間目）

拡張したへンレ氏係蹄内に赤血球及び円形の有形成分が認められる。オスミウム酸固定, epon 包埋, toluidine blue 染色. $\times 1800$

9) 両側尿管結㷊腎の光顕像（結樂後28時間目） 系球体の組織像.上方にボウマン露上皮細胞（B C ）があり，尿腔内（U S ）には円形の濃染せる顆粒が存 在する.オスミウム酸固定, epon 包埋, toluidine blue 染色. $\times 1800$

10) 正常腎の光顕像

Gomori 氏法による酸フォスファターゼ染色で, 近位尿細管上皮内に陽性物質が認められる。グルタールフ ルデヒド固定, 酸フオスフフターゼ染色. $\times 200$

11）両側尿管結紮腎の光顕像（結禁後 24 時間目）

Gomori 氏法による酸フオスファターゼ染色で, 正常腎と同様に近位尿細管上皮にその存在が認められる. グルタールアルデヒド固定, 酸フオスターゼ染色. $\times 200$

12) 両側尿管結禁腎の光䫓像（結禁後24時間目）

Gomori 氏法による酸フオスファターゼ染色で, 附図11の拡大像であるが，硫化アンモニウム溶液で発色す る大きな陽性顆粒 (矢印) が見られる.グルタールアルデヒド固定, 酸フォスファターゼ染色. メ 400

13）両側尿管結紫腎の電顕像（結禁後24時間目） 系球体上皮細胞内に電子密度の低い無構造の空胞が現われる (V). $\times 20700$ 
14) 両側尿管結禁腎の電顕像（結禁後28時間目）

糸球体上皮細胞内に巨大空胞が形成され（V)，それが尿腔内（U S ）に大きく突出している。 $\times 7100$

15) 両側尿管結禁腎の電顕像（結禁後34時間目）

尿腔（US）に遊離して見られた巨大空胞（V)，限界膜は明らかに二重の膜で形成されている(矢印). $\times$ 10200

16) 両側尿管結禁腎の電顕像（結禁後28時間目）

系球体上皮細胞. Golgi 装置がよく発達している。 Golgi sac(GS), Golgi vacuole (GVac), Golgi vesicle (GVes) がよく見られるが，その他に変化はない、× 14200

17）正常腎の電顕像

近位尿細管上皮細胞. 右上方に microvilli，左下方に基底膜が見られ，多数の mitochondria（M) その間に lysosome (Ly) 及び Golgi 装置をみる。 $\times 3700$

18）正常腎の電顕像

近位尿細管上皮細胞. ぎつしりとつまつた mitochondria (M) の間に lysosome (Ly) 及び Golgi 装置 をみる。 ×9200

19）両側尿管結禁腎の電顕像（結紮後18時間目）

近位尿細管。管腔は開存し, microvilli 直下の空胞の增大 ( A V ) と lysosome 様構造の空胞が認められる. $\times 7800$

20) 両側尿管結禁腎の電顕像（結禁後24時間目）

近位尿細管. microvilli の間より荎部によつて細胞と連絡をもつたまま，細胞質の一部が尿細管々腔内に突 出して巨大空胞を形成している。 $\times 11100$

21）両側尿管結紫腎の電顕像（結禁後28時間目） 近位尿細管々腔内．拡張した尿細管々腔内に上皮細胞と遊離した空胞構造が認められる． 14700

22) 両㑡尿管結禁腎の電顕像（結禁後28時間）

近位尿細管上皮細胞. 管腔側の細胞全体が microvilli を伴なつたまま管腔内に突出している。両端は terminal bar (T) で境されている. ×4000

23) 両側尿管結禁腎の電顕像（結禁後36時間目）

近位尿細管の上皮細胞の管腔側約 $1 / 3$ が無構造となり管腔内に突出している. microvilli の一部消失を見る. $\times 3900$

24）両側尿管結禁腎の電顕像（結禁後38時間目）

近位尿細管。上皮細胞の一部が破壞され，変形した mitochondria 等細胞成分が管胞内に見られる。 basal intussusception 不明瞭となる。 $\times 5500$

25）両側尿管結禁腎の電顕像（結禁後28時間目）

近位尿細管。中央から上方にかけて管腔が見られ， microvilli 直下の空胞（AV）の著明な增大を認める. $\times 5200$

26) 両側尿管結禁腎の電顕像（結禁後28時間目）

近位尿細管上皮細胞内に大きくなつた楕円形の lysosome 様構造 (LyV) が認められる。 $\times 4500$

27 ) 両側尿管結禁腎の電顕像（結禁後36時間目）

近位尿管上皮細胞内は lysosome 様構造 (LyV) の巨大空胞によつてその大部分を占められてくる. 空胞内

には変形した mitochondria（矢印）や電子密度の高い顆粒を含む。 ×5200

28) 両側尿管結禁腎の電顕像（結禁後38時間）

lysosome 様構造の空胞は互に融合し，不正形となり， mitochondria は圧迫され，細胞内は殆ど空胞のみに よつて占められている。 × 14000

29) 両側尿管結禁腎の電顕像（結禁後28時間目）

lysosome 様構造の空胞で,一重の膜で境されている。一部不明瞭の所（矢印）も見られる。内部にはミエ リン様構造物を含んでいる。 × 11800

30) 両側尿管結禁腎の電顕像（結禁後36時間後）

右方の近位尿細管に著明な空胞（V) が見られるに反し，ヘレン氏係蹄，集合管には変化は認められない。 $\times 1800$

31）両側尿管結禁腎の電顕像（結禁後24時間目）

払張したヘンレ氏係蹄の管腔内に赤血球及び円形の有形成分が認められる。×4900

32 ) 両側尿管結禁腎の電顕像（結禁後28時間目）

拡張した遠位尿細管々腔内に変形した mitochondria や電子密度の高い顆粒, 円形の有形成分が認められ る. $\times 7300$ 
33）両㑡尿管結禁腎の電顕像（結禁後38時間目）

左上方に近位尿細管，右下方にボウマン氏囊上皮が見られ，その間の間質が離開し間質細胞と間隙（I S ） が見られる。 × 15000

34) 両側尿管結禁腎の電顕像（結禁後18時間目）

近位尿細管上皮細胞で, microvilli 直下の空胞とそれょり電子密度の高い空胞との連絡した像（矢印）が認 められる。 × 10800

35）正常腎の電顕像

固定の際に近位尿細管上皮細胞内に現われる空胞の所見で，大きな無構造の空胞が中央に見られる．矢印で 示す如くそれは basal intussusception と連絡している. ×8300

36) 片側尿管結禁腎の電顕像（結禁後24時間目）

近位尿細管上皮細胞内にも両側尿管結禁群に見られたと同じ lysosome 様構造の空胞を認める.しかし，そ の数は両側尿管結禁群に比してずつと少ない. ×6000

\section{文献}

1) Anderson, M.S. and Recant, L.: Am. J. Path., 40, 555, 1962.

2）阿會佳郎：日泌尿会誌，53，243，1963.

3) Bulger, R.E.: Am. J. Anat., 116, 237, 1965.

4) Bennett, H.S. and Luft, J.H.: J. Biophys. Biochem. Cytol., 6, 113, 1959.

5) Brewer, D.B. and Eguren, L.m.: J. Path. Bact., 83, 107, 1962.

6) Caulfield, J.B. and Trump, B.F.: Am. J. Path., 40, 119, 1962.

7) Dalton, A.J., Kahler, H. and Lloyd, B.J.: J. Nat. Cancer Inst, 11, 1163, 1951.

8) Dalton, A.J., Kahler, H., Striebich, M.J. and Lloyd, B.J.: J. Nat. Cancer Inst., 11, 439, 1950.

9) Farquhar, M.G., Vernier, R.L. and Good, R.A.: Am. J. Path., 33, 791, 1957.

10) Farquhar, M.G., Vernier, R.L. and Good, R.A.: J. Exp. Med., 106, 469, 1957.

11）藤崎茂：日腎誌，3，19，1961.

12) Folli, G.: Ann. Int. Med., 00, 775, 1958.

13) Fujibayashi, T. et al.: Med. J. Osaka Uni., 11, 241, 1960.

14) Gibbons, I.R. and Grimstone, A.V.: J. Biophys. Biochem. Cytol., 7, 697, 1960.

15) Gomori, G.: Stain Tech., 25, 81, 1950.

16) Gottscholk, C.W. and Mylle, M.: Am. J. Physiol., 185, 430, 1956.

17) Gömöri, P. and Takacsy-Nagy, L.: Urol. int., 10, 385, 1960.

18) Gloor, F. and Neiditsch-Halff, L. A.: Z. Zellforsch., 66, 488, 1965.

19）間泉三他：日腎誌，7，74，1965.（抄録）

20 ) 平井英 : 日大医誌, 19, 3668, 1960.

21）壁島美雄 : 東京医学会誌, 42, 1516, 1928.

22) Janigan, D.T., Santamaria, A. and Trump, B.F.: J. Histochem. Cytochem., 8, 385, 1960.

23) Luft, J.H.: J. Biophys. Biochem. Cytol., 9, 409, 1961.
24) Maunsbach, A.B., Madden, S.C. and Latta, H.: J. Ultrasctrac. Res., 6, 551, 1962.

25) Millonig, G.: J. Biophys. Biochem. Cytol., 11, 736, 1961.

26) Novikoff, A.B.: J. Biophy. Biochem. Cytol., 6, 136, 1959.

27）岡直友他：日泌尿会誌，53，1，1962.

28) 岡田高明: 日大医誌, 19, 3693, 1960.

29) 大島研三：日内会誌，46，852，1957.

30) 大島研三 : 総合臨床, 6, 2261, 1957.

31）大島研三：日本臨床， 16，1401，1958.

32）大沢源吾 : 日腎誌, 5, 157, 1963.

33) Pease, D.C.: Anat. Rec., 121, 723, 1955.

34) Pease, D.C.: J. Histochem. Cytochem., 3, 295, 1955.

35) Palay, S.L. et al.: J. Cell. Biol., 12, 835, 1962.

36) Ruska, H., Moore, D.H. and Weinstock, J.: J. Biophys. Biochem. Cytol., 3, 249, 1957.

37) Rollhäuser, H. and Vogell, W.: Z. Zellforsch., 47, 53, 1957.

38）坂口弘, 鈴木康之亮 : 総合医学, 15, 672, 1958.

39 ）坂口弘, 鈴木康之亮, 李泰永 : 総合医学, 16 , 541, 1959.

40）清水隆秀：日泌尿会誌，53，201，1962.

41）関正利他：日腎誌，16，66，1964.（抄録）

42）田中茂樹：日腎誌, 7, 347, 1965.

43) 高須秀弆：第53回泌尿器学会総会, 1965(抄録).

44）竹内正他：日腎誌，5，305，1963.

45) Watson, M.L.: J. Biophy. Biochem. Cytol., 4, 475, 1958.

46) Wachstein, M.: J. Histochem. Cytochem., 3, 246, 1955.

47) Walker, A.M. and Oliver, J.: Am. J. Physiol., 134, 580, 1941.

48) Wilmer, H.A.: Am. J. Physiol., 141, 431, 1944.

49) 矢野久雄：日泌尿会誌，56，795，1965.

50) Yoshida, F. and Nakamura, M.: Okajimas Fol. anat. jap., 41, 121, 1965.

（昭和43年 4 月10日受付） 